\title{
$\mathbf{J X}$

\section{Relations of the United States with Sweden}

BY

KNUTE EMIL CARLSON

648

\section{A THESIS}

PRESRNTED TO THE FACULTY OF THE GRADUATE SCHOOL iN PARTIAL FULFILLMENT OF THE REQUIREMENTS FOR THE DEGREE OF DOCTOR OF PHILOSOPHY.

H. RAT HAAS \& CO. Printers and Publishers Allentown, $\mathbf{P a}$. 


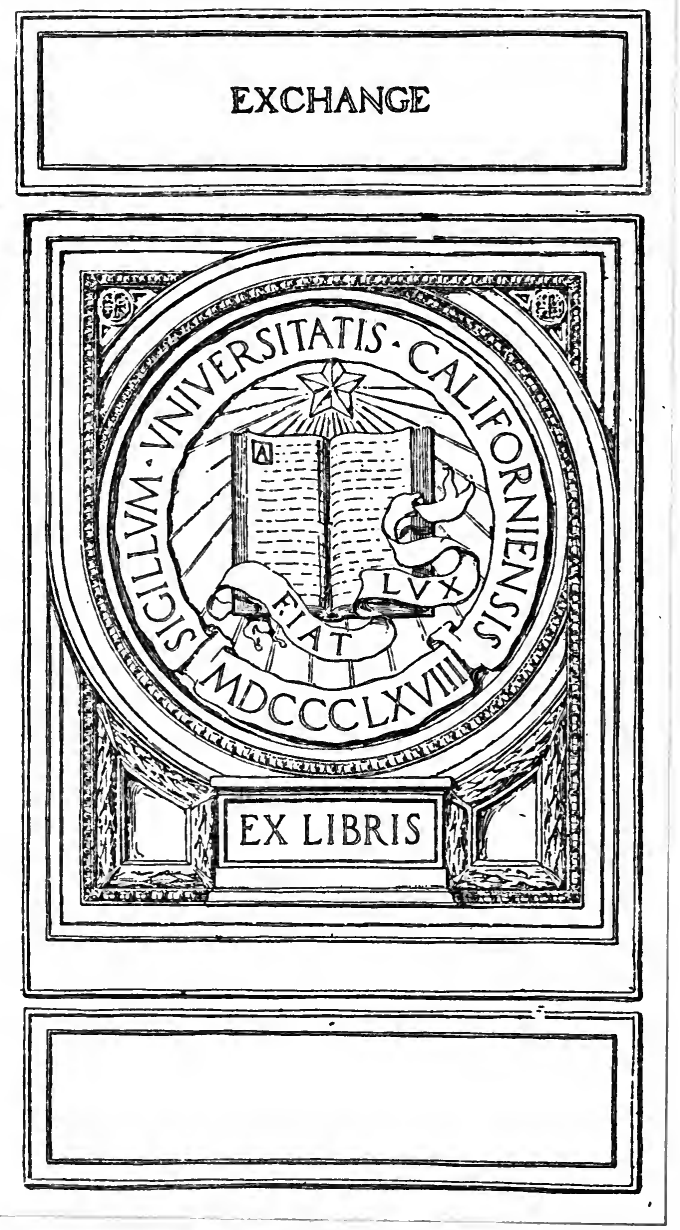



Digitized by the Internet Archive in 2007 with funding from Microsoft Corporation 
. 



\section{Relations of the United States with Sweden}

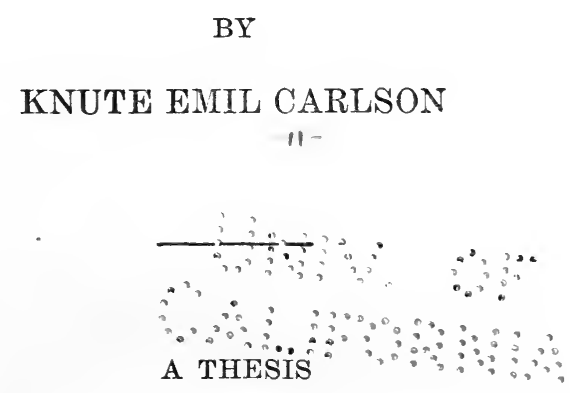

Presented to the Faculaty of the Graduate School in Partial Fulfillment of the Requirements for the Degree of Doctor of Philosophy.

H. RAY HAAS \& CO.

Printers and Publishers Allentown, Pa. 1921 


\section{$J \chi 1428$ \\ $\mathrm{SaC}_{3}$}

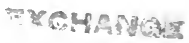

COPYRIGHT, 1921,

BY

KNUTE EMIL CARLSON

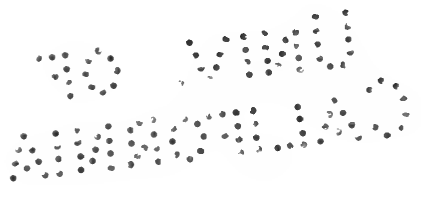




\section{INTRODUCTION}

The world war has emphasized the already apparent fact that the United States had become a world power that must be considered in a settlement of all important international questions. Other nations thought that the United States was too much absorbed in her own economic and industrial pursuits to take any part in world problems, but she has proved in this war that her interests are wide as the world. The United States has also proved that economic development has not prevented the fostering of advanced ideals in regard to international relations. These ideals have grown up with the nation and are not a recent outburst of patriotic emotion.

In the light of this general fact it has been considered important to study more carefully the negotiations between the United States and Sweden to ascertain the nature of the relations with that country, the problems that have been involved, and how those problems have been solved. A study of those negotiations has revealed the following facts:

First, Sweden assumed a decidedly friendly attitude toward the United States from the very beginning and this friendship is illustrated by the fact that Sweden was the first nation to ask the privilege to make a treaty with the United States as early as 1784 , by opening up of the island of St. Bartholomew as a free port in order to aid in the development of the mutual commerce, and by requesting the exchange of public ministers.

Second, when the two countries were suffering from the effects of the war between England and Napoleon, Sweden invited the United States to join in a league of neutral nations to protect the interest of the neutrals. This proposition was con- 
sidered by the American Government, which fact is proved by the instructions to John Jay and the correspondence between James Monroe and the Secretary of State.

Third, the Napoleonic wars brought on claims against Sweden as well as against other European powers, for she also became involved in the Continental System. Although the indemnity losses incurred was tardily agreed upon, the Swedish Government always frankly admitted the justice of the claims of the American merchants and expressed willingness to pay the indemnity. This willingness, on the part of the Swedish Government, to settle the claims is illustrated by the fact that the Crown Prince offered a quantity of cannons and gun powder, his personal property, as a payment on the claims, and also that the Government offered to sell the island of St. Bartholomew to the United States and to deduct from the purchase price the amount of the claims.

Fourth, Swedish consular officers tendered their good ser. vices in behalf of American sailors and American commerce in Algiers.

The source material used in preparing this study is indicated in the footnotes and in the appended bibliography. The material listed there has been carefully examined, and all irrevelent material has been omitted from the bibliography.

At present only the earlier part of the study of the relations between the two countries is published, but it is the intention of the author, as soon as recent material becomes available, to publish also that part of the study which deals with the problems growing out of the world war. 


\section{CONTENTS}

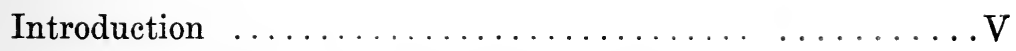

Chapter I. Negotiations During the American Revolution 1

Chapter II. Proposed Alliance .................. 26

Chapter III. The Stralsund Claims .............. 45

Chapter IV. Commercial Negotiations .............. 72

Select Bibliography $\ldots \ldots \ldots \ldots \ldots \ldots \ldots \ldots \ldots \ldots . \ldots . \ldots 1$ 



\section{CHAPTER I}

\section{Relations During the American Revolution}

The Declaration of Independence required as a necessary consequence the establishment of foreign relations. Before that time the inhabitants of the eastern shore of North America had belonged to a European Power, and their relation with other nations was therefore part and parcel of the European balance of power. When independence was declared and on the way to become a fact these inhabitants were no longer a mere attachment to another power. The question that must be decided, however, was whether these young states should send representatives to other nations to request admission into the family of nations, or should they quietly await until independence had been achieved and let the commercial advantages of the country solicit the invitation from older nations. The latter view was stated in a letter from Dr. Franklin to Arthur Lee when he was on his fruitless mission to Spain. He said: "A virgin state should preserve the virgin character, and not go about suitoring for alliances, but wait with decent dignity for the application of others." 1

Another class of statesmen with a "broader appreciation of political necessity" advocated a policy of diplomatic advances. The question of independence involved, from their point of view, a great number of European interests, and they deemed themselves warranted in demanding effective support in exchange for commercial opportunities. The personification of this poli-

${ }^{1}$ Sparks, J. Diplomatic Correspondence, II, 57; Franklin to Lee, March 21, 1777. 
cy seems to be John Adams who wrote: "I think we have not meanly solicited for friendship anywhere. But to send ministers to every court in Europe, especially the maritime courts, to propose an acknowledgement of the independence of America and treaties of amity and commerce, is no more than becomes us, and in my opinion is our duty to do. It is perfectly consistent with the genuine system of American policy, and a price of respect due from new nations to old ones". ${ }^{2}$ Already about a month earlier he had written to the President of Congress : "The counsels of the sovereigns of Europe are not easily penetrated; but it is our duty to attend to them, and throw into view such information as may be in our power, that they may take no measure inconsistent with their and our interest for want of light-a misfortune that may easily happen. In this view, I could wish that the United States had a minister in each of the maritime courts-I mean Holland, Russia, Sweden, and Denmark and, as the cabinet of Berlin has much influence in the politics of Europe, Prussia"'. ${ }^{3}$ Arthur and William Lee also wrote to Congress "stating that they were informed by reliable authority that Spain, Holland, Prussia, Germany, Tuseany, and Sweden were anxious to receive American ministers". " Fortunately for the young republic the latter view prevailed.

The war of the American Revolution had not proceeded far before the European nations became involved in one way or another, since England "claimed the right to search neutral vessels for contraband of war, and she exercised this right in a high-handed manner'. Finding it impossible to obtain redress from England, Gustavus III, of Sweden instructed his minister at London (December 1778) to deliver a remonstrance to the 1780 .

${ }^{2}$ Sparks, Diplomatic Corresp., V; 361; Adams to Franklin, October 14,

Wharton, F. Revolutionary Diplomatic Corresp., IV, 57; Adams to the President of Congress, September 16, 1780

-Wharton, Revolutionary Diplomatic Corresp., I, 460. 
English Government "couched in such sharp terms that Lord Suffolk expressed himself unable to distinguish it from a formal declaration of war". $•$

This action on the part of Sweden must have been fairly well considered for already in October the court of Denmark through its envoy in Stockholm inquired if the armed neutrality of 1756 ought not to be renewed. ${ }^{\circ}$ The King of Sweden answered in a cordial tone that he wished once more to appeal to England if perchance any relief would be granted without adopting extreme measures. But at the same time Gustavus III requested his minister in Russia to find out if Russia would co-operate. About the end of December 1778 the Empress of. Russia answered that she would co-operate if it became necessary.

When the protest of Sweden failed to bring about the necessary relief from England, the King of Sweden proposed to Denmark and Russia that the northern powers should protect their commerce by entering into a convention. This action on the part of Sweden was well known to England for on December 22, 1778, the British Ambassador of Petrograd wrote to the Earl of Suffolk regarding the contemplated action in the following words, "I trust your Lordship will not tax me with negligence, if the messenger is not yet departed. I cannot prevail on Count Panin to give me an answer, and I depend so little on his promise of his enabling me to despatch him to-morrow, that I lose no time in acquainting your Lordship, that on Saturday last the Swedish Minister after enlarging greatly on our conduct towards neutral ships, made a formal proposal to this Court to join with that of Stockholm in forming a combined fleet, sufficiently strong to protect the trade of the north against

- Bain, Gustavus III and his Contemporaries, I, 210; Fenberg, Sveriges Historia, V, 299.

- Albedyhll, Recueil de memoire., 15. 
the attacks made upon it. Mr. Nolken [the Swedish ambassador at Petrograd] added, that, if the Empress adopted this plan, there was no doubt that Denmark would also subscribe to it; and that the commerce of these countries, now so interrupted, would be by this means carried on with security". " The Ambassador continued, "I have reasons to believe the idea of taking so violent a measure as that of arming an united naval force was immediately rejected; but that, that of the trade of these countries being illegally interrupted, and the necessity of devising proper methods for its better security, was fully ad. mitted". 8

The foreign affairs of Denmark were conducted at this time by Andreas Peter Bernstorff sr., and his policy had always been hostile to Sweden. One writer states that "the insuperable jealousy between Sweden and Denmark, and the disinclination of Russia to offend England, prevented for a time, the formation of a Northern League". ' Count Bernstorff worked out a plan of co-operation between Denmark and Russia expecting to leave Sweden outside of the confederation. Russia. however, had not the same interest in protecting neutral commerce as the two Scandinavian states, because its shipping, outside the Baltic, was negligible, and privateers could therefore, in fact, only disturb the commerce to and from Archangel; but this commerce was carried on mainly by the English themselves. ${ }^{10}$

While Russia hesitated to enter whole-heartedly into a convention to protect the commerce of neutral nations, Sweden invited other neutrals to send delegates to "a congress at Stockholm in 1778" to induce Russia to head a league for arming the neutrals. Dr. Franklin must have known about this congress

'Malmesbury, Diaries and Correspondence, I, 189.

- Ibid. 189.

- Bain, Gustarus III, and his Contemporaries, (1746-1792), I, 210.

${ }^{10}$ Hildebrand, Sveriges Historia, VIII, 54. 
for he wrote about it to the Danish minister approving a claim for compensation for attending such a convention on December 25,1778 , in the following words: "I have considered the proposition, and see no objection to it. I will write to Congress in favor of it, if desired". ${ }^{11}$

On December 31, 1778, the English Ambassador at Petrograd again wrote about this subject to the Earl of Suffolk as follows: "In one of his last conversations he [Count Panin] told me that he was obliged to express Her Imperial Majesty's wishes, that we should put a little more circumspection in our mode of proceeding against the ships of Neutral States; that we should otherwise irritate powers now well disposed toward us; that Denmark, Sweden, and Holland had respectively solicited the Empress to join with them in a representation to us on this subject"'. 12

The northern neutrals did not stop with mere protests for. on February 14, 1779, the Swedish envoy at Petrograd was requested to make a proposal to that court, ${ }^{13}$ and on the 18th of the same month, the King of Sweden, after having reached an agreement with Denmark, issued a declaration according to which the two nations were to convoy their merchant vessels. About this agreement John Adams wrote to Arthur Lee: "The declaration of the Northern Powers against the right of England to stop their merchant vessels and arming to support their rights are important events'. ${ }^{14}$ Russia had promised to help protect the commerce which went north of Norway, and, although Denmark considered this offer unsatisfactory, Sweden, anxious to obtain any improvement in her relation with Russia, accepted whatever could be obtained for the time being. It was this con-

${ }^{11}$ Wharton, The Revolutionary Diplomatic Corresp., I, 618.

"Malmesbury, Diaries and Correspondence, I, 190.

* Albedyhll, Recueil de memoire, 18.

14 Wharton, Revolutionary Diplomatic Corr., III, 214; Adams to Arthur Lee, June 9, 1779. 
federation to which John Adams referred when he wrote to the President of the Continental Congress: "Russia, Sweden, and Denmark, comprehended under the denomination of the northern powers, have been thought by some to be interested in our return to the denomination of Great Britain. Whether they consider themselves in this light or not, their late declarations against the rights of England to interrupt their navigation and their armirig for the protection of their commerce on the ocean, and even in the English channel, are unequivocal proofs of their opinion concerning the right in our contest and of their intentions not to interfere against us......". ${ }^{15}$

The burden of arming the convoys fell rather heavily on Sweden, for Russia's aid was faultering and doubtful, and Denmark began to negotiate with England anew for the amelioration of commercial restrictions. ${ }^{16}$ For Sweden, however, any understanding with Russia was preferable to the condition that preceded the adoption of the convention; besides that she could render effective aid to her old friend and ally, France, in her endeavor to assist the young American Republic.

The fundamental principles of the convention between Sweden and Denmark were repeated almost verbatim in the convention proclaimed by Russia on March 10, 1780. Although the formulation of these principles did not effect any compro. mise on the part of Great Britain, their formulation and enforcement by an armed force of nations constituted an advance in the history of public law.

Early in 1780, however, when Spain sunk two Russian merchant vessels, Russia became at once interested in a more vigor ous enforcement of the principles contained in the convention of the armed neutrality; and the Empress Catherine II, invited Sweden and Denmark to join with her to protect their commerce

\footnotetext{
${ }^{16}$ Wharton, Op. Cit., III, 285.

${ }^{16}$ Hildebrand, Sveriges Historia, VIII, 54.
} 
against disturbances of hostile fleets. At this time Denmark was less interested in the enforcement of neutral rights than a year and a half earlier, for in the meantime she had entered into a treaty with England which would grant her most of the privileges she desired, but Russia finally induced Denmark to join.

The following principles, quoted almost word for word from the earlier convention, constituted the basis of the armed neutrality on which Russia invited her neighbors to join with her :

1. "That all neutral vessels ought to navigate freely from one port to another, as well as upon the coasts of the powers at war;

2. "That the effects belonging to the subjects of the belligerent powers shall be free in neutral ships, excepting always contraband goods ;

3. "That her imperial majesty, in consequence of the limits above fixed, will adhere strictly to that which is stipulated by the tenth and eleventh articles of her treaty of commerce with Great Britain, concerning the manner in which she ought to conduct herself toward all the belligerent powers;

4. "That as to what concerns a port blocked up, we ought not, in truth, to consider as such any but those which are found so well shut up by a fixed and sufficient number of vessels belonging to the power which attacks it that one cannot attempt to enter into such a port without evident danger;

5. "That these principles alone laid down ought to serve as a rule in all proceedings whenever there is a question of legality of prizes"'. ${ }^{17}$

${ }^{17}$ Wharton, Op. Cit., III, 608; cf. Malmesbury, Diaries and Corres. pondence, I, 251. 
From the facts stated above, it becomes clear that the armed neutrality was in force prior to the proclamation of Catharine II, and that it originated with Sweden and Denmark rather than with Russia. As a matter of fact the armed neutrality of 1779 . 1780 was only a fruitition of earlier agreements to the same effect. If an attempt is made to find the origin of the idea, and the principles involved, it becomes necessary to go back into the close of the sixteenth century. Those agreements, far less known than the later one, were nevertheless effective in bringing about the desired end; and the honor for their establishment belong to Denmark and Sweden; the first thought about it undoubtedly emanated from Denmark.

It was during the war of the allied powers against Louis XIV that England and Holland entered into an agreement, in August 1689, which united their powers under William III, to checkmate France. According to the first article of their agreement all commerce with France was to be prohibited. This treaty contradicted earlier treaties between these countries and the northern powers; and when the privateers began to make commerce dangerous the governments of Sweden and Denmark became uneasy. For this reason the Danish Government instructed its minister at the Court of Sweden to propose that a united force of armed vessels be fitted out to convoy their merchant vessels. Sweden whose politics at this time was otherwise hostile to Denmark, consented to the proposal and the result was the "Tractat till Navigationens och Commerciens sakerhet" (A Treaty for the Safety of Commerce and Navigation), which was concluded at Stockholm, March 10, 1691, and was renewed by the Danish Minister Jens Juel, March 17, 1693. These are the earliest agreements of their kind and were not without results, for both England and Holland found themselves 
obliged to make good the losses sustained by the northern powers. ${ }^{18}$

The third league of nations to enforce the right of neutral commerce was brought about on July 12, 1756 by signing of a formal convention at Stockholm. ${ }^{19}$ It was later extended in 1759 by the entrance of Russia. The existence of this union and the reason for it do not seem to be very well known to English readers, but, because this union is closely related to the later one, a short account of it may be included here.

The events are intimately connected with the seven years war. The war which broke out in the American colonies between France and England had not even been officially declared when English vessels began to visit and search all merchant vessels en route for France. The question of contraband became especially important, but since the treaty of peace at Utrecht, 1713, [parg. XIX,XX] specifically stated what was to be considered contraband, this question ought to have been rather easily solved. But the English Government made a different application of the rule in each instance and counted as contraband many other commodities known only to their own privateers. Thus the old selfish system was in full swing. Very soon the effects of this system became known among the northern powers. Already in August 1755 England's disregard for neutral rights went so far that an English frigate, sent to the sound to convoy English vessels home, visited and searched a Swedish vessel just outside of Helsingor, under the pretense that it was searching for goods destined to France. This act was performed right under the Danish guns on Kroneborg;

14 For a summary of the agreements seo Sprinchorn, Ett bidrag till den vapnade neutralitetens historia i Norden in Historisk Tidskrift (1881. 82), I, 248. For a full discussion of the earlier treaties see Reedlz, H. C. Danmarks og Sveriges forbindelse till de neutrala handelsrettigheters beskyttelse i aarene 1690 till 1693; De Bkand. literatselskapes skrifter, 21 Bend. Copenhagen 1826.

* Albedyhll, Recueil de memoire, 11. 
therefore the act aroused the indignation of the Danish Government, and Baron Bernstorff sr. who together with A. G. von Moltke controlled the politics of Denmark, instructed the Danish envoy at London to unite with the Swedish Minister in a protest. Von Moltke also suggested to the Swedish minister at Copenhagen that Sweden and Denmark ought to agree on a plan to safeguard their shipping during the war between France and England. The negotiations proceeded rapidly and in February 1856 a plan was submitted to a secret committee of the Riksdag. The proposition was read, discussed and approved in about half an hour, which fact may indicate the care with which the proposition had been prepared by the Government. After a counter proposition was received from Denmark, a mutual agreement was reached and the convention was signed July 12, 1856. ${ }^{20}$

The Proclamation of Catharine II, on March 10, 1780, came therefore, not, as has been often assumed, as something entirely new and unheard of, but as an expression of the experience of the northern nations. ${ }^{21}$ The principle which the earlier agreements had tested were embodied in the new one. The only exception was the agreement of 1756 wherein Denmark objected to the principle of free ships, free goods, on the ground that she did not desire unnecessarily to offend England.

The declaration of the northern neutrals struck at the very center of English interests. "In some confused minutes of a debate in the House of Lords on the 14 of April [1780] it is said that Lord Camden expressed his astonishment and regret

${ }^{20}$ Sprinchorn, C. Ett bidrag till den vapuade neutralitetens historia i Norden, in Svensk Historisk Tidskrift (1881-2), I, $250 \mathrm{f}$.

${ }^{21} \mathrm{Mr}$. Bain in Gustavus III, and his contemporaries, I, 149, asserts that the action of Catharine II, was taken in revenge because England would not co-operate with her in suppressing the revolution in Sweden 1772; therefore when England asked for 20,000 soldiers to restrain "the increasing frenzy of his Majesty's unhappy and deluded people on the other side of the Atlantic,' and a draft treaty to that effect was actually sent to Gunning, Catharine II explained away her promise. 
at the memorial from Russia..... . The thought of that manifesto made him shudder when he first read it, particularly as he knew how his country stood in respect to other powers..... ", ${ }^{22}$ John Adams significantly added that if the Court of England had had only common information "they would have known that this combination of maritime powers has been forming these eighteen months, and was nearly as well agreed to a year ago as it is now',. ${ }^{23}$

England did not, however, willingly accede to the principles of the armed neutrality for she held that Sweden was inspired by an excessive friendship for France and therefore also for the United States. The measure she adopted to counteract the armed neutrality seems therefore specifically aimed against Sweden. John Adams wrote about it to the President of Congress on April 4,1780 , in the following words: "The Swedish frigate Illerim, of thirty-four guns, commanded by Captain Ankerloo, on the 28 of February, at half after eight o'clock at night, met an English privateer belonging to Minorca, of twenty-eight guns. The Swedish eaptain after hailing the privateer, let her continue her course, and went on quietly his own: about half an hour after, the privateer returning ranged herself astern of the frigate and unexpectedly discharged both his broadsides, loaded with langrage, which killed three sailors, broke the thigh and right leg of the Captain, wounded the Lieutenant and some people of the crew. Ankerloo, who in the evening had been obliged by a violent gale of wind to draw in his guns and shut up his ports, not finding himself prepared for battle, his officers took immediate measures, with the utmost alertness, for repulsing the privateer, which did in fact at last receive a broadside from the frigate; but on the whole, she escaped in the night, by the force of sails and oars. After this perfidy on the part of the English, Anker- 
loo would have entered Marsailles for the sake of dressing his wounds, but having met with contrary winds and bad weather for three days, he put into Malaga, where he went ashore to the house of the Swedish consul, where he is since dead of wounds". 24

England even claimed the right to search merchant vessels under convoy. The following has been taken from a report to the President of Congress from John Adams dated January 16, 1782. "They write from Stockholm, that the Court of London has thought proper to make representations to that of Sweden, concerning a recounter, which a convoy of merchant ships, under escort of the Swedish frigate, the Jaramas, had. with the English squadron of commodore Stewart, who would have visited these ships. The Court of London pretends that he was authorized to make such a visit, even in virtue of the articles of the convention of the armed neutrality, concluded between the three powers of the north; but that the court of Stockholm, far from blaming the refusal of the captain of the Jaramas, to permit the visit, had highly approved his conduct, and answered that this officer had acted conformably to his duty, for that the regulation in one of the articles of the convention of the armed neutrality in regard to the visit of merchant ships, respected only vessels, which navigated without convoy, but not at all those which should be found under convoy; and consequently under the protection of a sovereign flag the warranty of the nature of their cargo, and of the property". ${ }^{25}$ The decision of the Court of Sweden was referred to Catharine II, and she approved it and assured the Swedish Government of her cooperation to defend the right of neutrals.

The Continental Congress carefully discussed the information received from the representatives in Europe, and on Sep-

" Sparks, J. Dipl. Corr., II, 699 f.

* Bparks, J. Dipl. Corr. of the Am. Bov., VI, 848. 
tember 26, 1780, a "committee to whom was referred the motion of Mr. [Samuel] Adams, reports that, Whereas her Imperial Majesty of all the Russias, animated with the clearest sentiment of Justice, equity and moderation, and a strict regard to the unquestionable rights of neutrality and the most perfect freedom of commerce that can consist with such neutrality has notified both to the belligerent and neutral Powers, the following propositions to which his Most Christian Majesty, the Illustrious ally of these United States and his Catholic Majesty two of the belligerent Powers, and most of the neutral Powers in Europe have acceded.

"The Congress of the United States of America willing to testify their moderation and regard to the rights of neutrality and freedom of commerce, as well as their respect for the Powers and potentates who have adopted the propositions have:

"Resolved, That all neutral vessels have by the Law of Nations a right to navigate freely to and from ports and on the coasts of the powers at war, when not prohibited by treaty or municipal law.

"That in the case aforesaid the effects of belligerent Powers, or belonging to their subjects shall be free in neutral vessels except always contraband. That the term contraband be confined to those articles expressly declared such by the articles of the Treaty of Amity and Commerce of the 6th day of February 1778, between his Most Christian Majesty and these United States.

"That with regard to ports or places blocked up or closely invested, none shall be considered as such but those which by a seige or blockade are so closely invested that an attempt cannot be made to enter such ports or places without evident danger.

"That the above principles serve as a rule in all proceedings of justice in the United States on all questions of capture.

"Ordered that the committee of Foreign Affairs transmit copies of the above act to the Minister Plenipotentiary of these 
States at the Court of Versailles to be by him communicated to the Neutral Powers in Europe and others whom it may concern". ${ }^{26}$

The same day, September 26, 1780, Robert Livingston introduced a resolution of the following content: "Congress have considered the declaration of the Empress of all the Russias, relative to the rights of neutral vessels. The regulations it contains are useful, wise, and just. The acts of a sovereign who promotes the happiness of her subjects and extends her views to the welfare of nations, who forms laws for a vast empire and corrects the great code of the world, claims the earliest attention of a rising republic therefore

"Resolved, That the Board of Admiralty report instructions for the commanders of armed vessels commissioned by the United States conformable to the principles contained in the said declaration.

"Resolved, That copies of the above resolution be transmitted to the Minister of the United States respectively, and to Monssre de Marbois, charge des affaires, from his Most Christian Majesty", ${ }^{27}$

On October 4 it was decided to consider the report on the resolution, relative to the armed neutrality of the north, on the following day. ${ }^{28}$ On the 5th, Congress took into consideration "the report of the committee on the motion relative to the proposition of the Empress of Russia; and thereupon came to the following resolution;

"Her Imperial Majesty of all the Russias, attentive to the freedom of commerce, and the rights of nations, in her declaration to the belligerent and neutral powers, having proposed regulations, founded upon principles of justice, equity, and

\footnotetext{
${ }^{20}$ Journals of Cont. Congress, XVIII, $864 \mathrm{ff}$.

${ }^{27}$ Journals of the Cont. Congress, XVIII, 866.

${ }^{28}$ Journals of the Cont. Congress, XVIII, 899.
} 
moderation, of which their Most Christian and Catholic Majesties, and most of the neutral maritime powers of Europe, have declared their approbation.

"Congress, willing to testify their regard to the rights of commerce, and their respect for the sovereign, who hath proposed and the powers that have approved the said regulations;

"Resolved, That the Board of Admiralty prepare and re.port instructions for the commanders of armed vessels commissioned by the United States, conformable to the principles contained in the declaration of the Empress of all the Russias, on the rights of neutral vessels;

"That the ministers plenipotentiary from the United States, if invited thereto, be and hereby are respectively empowered to accede to such regulations conformable to the spirit of the saiu declaration, as may be agreed upon by Congress expected to assemble in pursuance of the invitation of her Imperial Majesty.

"Ordered, That copies of the above resolutions be transmitted to the respective ministers of the United States at foreign courts, and to the honorable the minister plenipotentiary of France". ${ }^{29}$

The Board of Admiralty reported November 27, 1780, giving the following instructions to the commanders of ships of war and private armed vessels:

1. "Permit all neutral vessels freely to navigate in the high seas or coasts of America, except such as are employed in carrying contraband goods or soldiers to the enemies of the United States;

2. "You shall not seize or capture any effects belonging to the subjects of belligerent powers on board neutral vessels, excepting contraband goods".

3. The term "contraband" should be interpreted in the light of the treaty of February 6, 1778, with France.

${ }^{29}$ Journals of the Continental Congress, XVIII, $905 \mathrm{f}$. 
4. Any one who violated those regulations should lose his commission.

5. These principles should serve as basis for determining the legality of prizes. ${ }^{\text {so }}$

In keeping with these instructions, Congress adopted a resoIution June 26, 1781, to request the Board of Admiralty to "inform John Barry Esq., commander of the frigate Alliance that Congress approve his conduct in releasing the ship belonging to subjects of the republic of Venice, retaken by him from a British privateer on the 4th of March last, it being their determination always to pay the utmost respect to the rights of neutral commerce" 31

The ministers plenipotentiary who represented the United States in Europe performed their part expeditiously. John Adams wrote to the President of Congress March 19, 1781, "1 have been advised to do nothing in consequence of my commission to the States at present, for fear of throwing before the people new objects of division and dissension. I have, however, communicated to their High Mightinesses and to the ministers of Russia, Denmark, Sweden, and France, the resolution of Congress of the 5 th of October, relative to the principles of the neutral confederation......'. ${ }^{32}$ And Dr. Franklin wrote to John Jay on April 12, 1781, "I thank you for sending me the copy of the Resolution relating to the Empress of Russia, tho' I had before received it, and was already communicated to her Imperial Majesty, who I am informed is much pleased with it"'. ${ }^{33}$

Congress also issued instructions to Mr. Dana, December 19,1780 , when he was sent to Russia authorizing him to "sub scribe to any treaty for that purpose" of protecting the freedom

ॠ Journals of the Cont. Congress, XVIII, 1097 ; comp. 1008.

"Journals of the Cont. Congress, XVIII, 1098; Journals of Congresx, VII, 109.

"John Adams' Works (ed. C. F. Adams), VII, 381.

${ }^{23}$ Life and Writings of Franklin (ed. Smyth), VIII, 238. 
of commerce and the rights of nations "conformable to the spirit" of the declaration, "and which is consistant with the dignity and sovereignty of the United States as a free and independent nation......". He was authorized to sign a treaty with any one of the neutral nations or with all of them, and to "use every means which can be devised to obtain the consent and influence of that Court that these United States shall be formally invited, or admitted to accede as principal and as independent nation to the said convention'. ${ }^{34}$

In a letter to Livingston, dated September 5, 1782, Francis Dana pointed out that Congress must "have misapprehended the nature of the Confederation proposed to maintain the freedom of commerce and navigation...... My commission and instructions are in part founded upon the supposition' that neutrals and belligerents alike were invited "to enter into a general convention for that purpose, and authorized me to accede to the same (if invited thereto) on the part of the United States, whereas the declaration is in the nature of a notification to the belligerent powers only, and contains a complaint of the interruption the commerce and navigation of neutral nations. . . . had suffered from the subjects of the belligerent powers, in violation of the rights of neutral nations". The proclamation stated those rights and to protect them the neutrals had fitted out the greater portion of their marine forces. ${ }^{35}$

Mr. Dana continued by saying that this was the only passage he had "been able to find in all the acts relative to this subject; which gives the least idea of a Congress for general negotiation". ${ }^{36}$

On January 3, 1783, Mr. Dana explained that the maritime

\footnotetext{
${ }^{34}$ Journals of the Cont. Congress, XVIII, 1168-73.

${ }^{35}$ Wharton, Dipl. Corr. of the Am. Rev., V, $700 \mathrm{ff}$.

${ }^{30}$ Wharton, Dipl. Corr. of the Am. Rev., V, 700.
} 
convention appeared "from its nature, as well as from its terms, to be limited to the duration of the present war". ${ }^{37}$

From the evidence at hand it seems fair to conclude that Russia did not mean to help the United States to establish thcir independence; she entered the armed neutrality for her own interest. Catharine II enjoyed the flattery and praise the resolution of the Continental Congress bestowed upon her, but she stubbornly refused to receive their minister. The French minister to the United States received a despatch from Count de Vergennes, dated March 9, 1781, of which he notified congress. Count de Vergennes considered "that the resolves of Congress which had been adopted on the association of the neutral powers, were found very wise by the council of the king; and that it was thought they might be of service in the course of the negotiations. The French ministry did not doubt that they would be very agreeable to the Empress of Russia. But they were not of the same opinion with the respect to the appointment of Mr. Dana, as a minister to the court of Petersburg'. The reason was that the Empress had expressed the greatest impartiality and expected that peace would be established only through her mediation. ${ }^{38}$

This question is further illustrated by a letter which Dr. Franklin received from Francis Dana, and which Dr. Franklin reported to Congress. He wrote: "This day I received a letter from Mr. Dana, dated at St. Petersburg, April 29, in which is the following passage: We yesterday received news, that the States General had on the 19th of this month acknowledged the Independence of the United States. This event gave a shock here, and is not well received, as they at least profess to have flattered themselves, that the mediation would have prevented it, and IV, 664 .

${ }^{37}$ Wharton, Dip. Corr. of the Am. Rev., VI, 194; Sparks, Dipl. Corr.,

${ }^{28}$ Journals of the Cont. Congress, XX, 562. 
otherwise bro't on a partial peace between Great Britain and Holland", ${ }^{39}$

In view of these facts it is not surprising that Hamilton made a motion in Congress, seconded by Madison on May 21, 1783, "that Dana be informed that the primary object of his mission to St. Petersburg was terminated, and that the benefits of a commercial treaty were remote and without present inducements". Mr. Hamilton also referred to the armed neutrality in the following words: "That though Congress approve the principles of the armed neutrality, founded on the liberal basis of a maintenance of the rights of neutral nations of the privileges of commerce, yet they are unwilling, at this juncture, to become a party to a confederacy which may hereafter too far complicate the interests of the United States with the politicks of Europe, and therefore, if such a progress is not yet made in this business as may make it dishonorable to recede, it is their desire, that no further measures may be taken at present towards the admission of the United States into that confederacy'. 40

From these facts it is clear that the policy of Russia was only to weaken both England and France so that she should be able so much more easily to pursue her policy toward Poland for its final partition. In the weakened condition, France would not be able to watch so carefully the Russian advances into Poland. Denmark was her ally and came into the armed neutrality under the pressure of Russia, because she had entered into a treaty with England which gave her partial satisfaction. Sweden, therefore, remains as the only member of the armed neutrality which on account of its friendship with France and the United States was willing to aid the friends. This is strik-

${ }^{30}$ Life and Writings of Franklin, VIII, 534.

${ }^{40}$ Journals of Congress, For. Affrs., 346; also in Writings of James Madison (G. Hunt, ed.), I, 469. 
ingly illustrated by the fact that Sweden was the first country to request a treaty with the United States, by the treatment of the American ministers by the Swedish ministers in Europe, and by their offer to grant United States vessels a haven of safety in the harbors of their country.

On December 20, 1781, Mr. Carmichael wrote to Robert Livingston from Madrid: "The new minister of Sweden is open in declaring his partiality for our cause, and signified that he would have waited on Mr. Jay on his arrival here, as it is the custom of those last come to do..... His conduct to myself shows that this was not a mere compliment, for he has invited me several times to dine with him, and visited me". ${ }^{41}$ In a similar spirit John Adams wrote from the Hague, September 4, 1782: "The minister from Sweden, the Baron d'Ehrenswerd, is lately removed to Berlin, to my great regret, as he appeared to me a very good character, and behaved very civilly to me several times when I met him at court and at the French ambassador's". ${ }^{42}$ Again John Adams wrote on November 19, 1782: "The Swedish minister went to a gentleman and asked him to introduce him to Mr. Jay and me, which he did. The minister told us he had been here since 1766". 4

Dr. Franklin reported on July 1, 1782, that "the ambassador from the King of Sweden" had asked him whether he had powers to conclude a treaty of commerce with Sweden. The minister said that his master "was desirous of such a treaty with the United States", and had directed him to ask Dr. Franklin that question. The King had charged his minister to tell Franklin "that it would flatter him greatly to make it with a person whose character he so much esteemed......". ${ }^{44}$

Regarding the treaty Franklin wrote to Livingston on

${ }^{41}$ Wharton, Dipl. Corr. of the Am. Rev., V, 62.

Wharton, Dipl. Corr. of the Am. Rev., V, 691

${ }^{43}$ Wharton, Dipl. Corr. of the Am. Rev., VI, 56.

${ }^{44}$ Wharton, Op. Cit., V, 558. 
August 12, 1782, in the following words: "I understand from the Swedish Ambassador that their treaty with us will go on as 'soon as ours with Holland is finished, and the treaty with France with such improvements as that with Holland may suggest, being the basis". ${ }^{45}$ The continental congress adopted a resolution September 19, 1782: "That a commission and instructions" should be issued "for negotiating a treaty of amity and commerce with the King of Sweden". Arthur Lee, Ralph Izard, and James Duane were appointed as a committee to draft the instructions. ${ }^{40}$ The committee was ready to report a plan for a treaty and instructions on September 28, 1782. The commission was issued to Franklin and in case of his death or incapacity to John Adams. ${ }^{47}$ The instructions were issued to Franklin "to negotiate and conclude the proposed treaty of amity and commerce with the person or persons that shall be appointed by his Swedish Majesty at Paris, and not elsewhere, unless some other place should be fixed upon for negotiating a general peace; in which case you may negotiate and conclude it at the same place". The Committee suggested that the treaty should run for twelve years only " as we shall be better able to judge by experience what commercial regulations will be most beneficial for the citizens and subjects of the contracting Powers".

The instructions continued by saying that "it is possible that the fourth article in the plan of a treaty may be objected to on the part of the King of Sweden, as unequal, he having more ships of war than the United States, and not being engaged in any war which may render protection necessary to the ships of his subjects. He may also apprehend, that the giving protection to our vessels may involve him in war with Great Britain. To this it may be answered that the fifteenth article is as unequal in favor of Sweden, giving her the benefit of the carrying trade,

\footnotetext{
* Wharton, Dipl. Corr. of the Am. Rev., V, 655.

${ }^{46}$ Journals of the Cont. Congress, XXIII, 592, 610.

${ }^{47}$ Journals of the Cont. Congress, XXIII, 621.
} 
which cannot be enjoyed by the citizens of the United States . . Therefore the one article may be set against the other."

The essential object of the treaty was declared to be "the recognition of our Independence by another European power." In order to obtain that Franklin was authorized, if necessary, not to adhere to the fourth article "to prevent the conclusion of the treaty." On the same principle he was authorized to use his discretion in extending the terms of the treaty to twenty years but no farther. He was also allowed to "recede from the stipulation proposed in the 9th article, that whatever shall be found laden by the Subjects and Inhabitants of either party on any ship belonging to the enemies of the other should be subject to confiscation." 48 During the debates Congress changed the time for the duration of the treaty to fifteen years instead of twelve as suggested by the committee. ${ }^{49}$

The American ministers in Europe also considered that an important victory had been won through the invitation from Sweden to form a treaty. On December 14, 1782, John Adams wrote to Robert Livingston from Paris: "There is more matter than time to write at present. The King of Sweden has done the United States the great honor in his commission to his Minister to treat with them, by inserting that he had a great desire to form a connection with States which had so fully established their independence, and by their wise and gallant conduct so well deserved it; and his Minister desired it might be remembered that his Sovereign was the first who had voluntarily proposed a treaty with us." 50 Only ten days later Franklin could write: "The Swedish ambassador has exchanged full powers with me. I send a copy of his herewith. We have had some conferences on the proposed plan of our treaty, and he has despatched a courier for further instructions respecting some of the articles." 51

${ }^{48}$ Journals of the Cont. Congress, XXIII, 622-24.

Writings of James Madison (G. Hunt, ed.), I, 243.

${ }^{5}$ Sparks, Dipl. Corr., IV, 3.

${ }^{51}$ Wharton, Dipl. Corr. of the Am. Rev., VI, 163. 
The work on the treaty progressed so rapidly that it could be signed on April 3, 1783. Shortly after the treaty was signed Count Gustavus Philip Creutz, who for seventeen years had been Minister at the Court of Versailles, was recalled to succeed Count Shaffer as secretary of Foreign Affairs. As his successor at Paris was chosen the young Baron Eric Magnus de Stael von Holstein, son-in-law of M. Necker, the French minister of finance. ${ }^{52}$

The treaty proper contained twenty-seven articles of which the first one provided for a "firm and universal peace" between the United States and Sweden. The treaty provided that if one country granted any commercial privilege to any other nation in regard to tariff or harbor facilities that privilege should also apply to the commerce between the two contracting parties. The principle of free ships, free goods, excluding contraband, was incorporated from the armed neutrality. In one article the treaty specified that contraband should include material of war, like arms, great guns, canon balls, and even matches. But contraband goods destined to an enemy country should not be confiscated outright until legal investigation had been completed in order to grant justice to the parties concerned. No privateer of either nation was allowed to take prizes from the other, but if a prize had been taken the person who had taken the prize was responsible in person and goods to make satisfaction to the injured party. In order that the government should be able to guarantee this last point, it should require from every person who wished to fit out a privateer a security so large that the treaty obligations could be fulfilled. If one nation should be at war and his enemy had taken vessels from its friendly ally, this one, if he retook the vessel, should return it to its lawful owner.

The treaty also prescribed the details to be followed if the two countries should be at war with a common enemy. The following procedure should be carried out:

${ }^{82}$ Bain, Gustavus III, etc., I, 254. 
1. If the vessel was retaken from the enemy by a man of war from the other nation, and the vessel had not been in the possession of the enemy more than 24 hours, then it should be returned to the original owner on paying one-third of the value of the ship and cargo ; if the vessel should have been in possession of the enemy more than 24 hours, it should belong to the captor.

2. If the vessel was retaken during the 24 hours, it should be returned to the owner on paying one-thirtieth of the value of the vessel and cargo, and one-tenth if retaken after 24 hours, for the crew of the capturing vessel.

3. Prizes taken in the above manner should be returned to the owner after he had given security to assure the earrying out of the above stipulation.

4. Privateers of one nation shall be admitted into the harbors of the other reciprocally.

The twenty-seventh article suggested that the treaty should be ratified within eight months, or sooner if possible, counting from the day of the signature. ${ }^{53}$

On July 29, 1783, Congress took up the treaty for consideration and with a few verbal changes it was "adopted and ratified by nine states being present." Congress thereupon authorized Benjamin Franklin "to deliver this our act of ratification in exchange for the ratification of the said treaty by his Majesty the King of Sweden." The act was signed by the President of Congress, Elias Boudinot on July 29, 1783, and of our sovereignty and independence the eight'". ${ }^{54}$

A committee consisting of James Madison, Mr. Higginson,

${ }^{63}$ Journal of the Am. Cong. (1774-1788), IV, 241 f., Malloy, Treaties, Conventions, and International Acts, II, 1725 ff., Secret Journal of Congress, III, 369.

${ }^{54}$ Journal of the American Congress (1774-1788), IV, 247. 
and Alexander Hamilton was appointed to draught a proclamation declaring the treaty in force, and the report was submitted and adopted on September 5, 1783. The proclamation required all the citizens and inhabitants, and "more especially all officers and others in the service of the United States" to govern themselves "strictly in all things according to the stipulations" of the treaty. ${ }^{55}$

${ }^{55}$ Journal of the American Congress (1774-1788), IV, 278. 


\section{CHAPTER II}

\section{Proposed Alliance}

"It appears that no powers are at present vested in any person in Europe to agree to any treaty similar to that entered into by Russia, Sweden, Denmark and the United Provinces of the Netherlands, after the peace shall be concluded", wrote Robert Livingston on June 3,1783 , in a report to Congress. ${ }^{1}$ Nine days later a committee of Congress took up the idea and said: "The resolution of the 5th of October, 1780, empowers the Ministers of these States, if invited thereto, to accede to such regulations conformable to the spirit of the declaration of Russia. . . . in pursuance of the invitation of her Imperial Majesty. Our Ministers received no invitation, and special powers were afterwards given to Mr. Dana, which, in their nature superceded that resolution. Mr. Dana was by his commission and instructions, empowered to sign the treaty, or convention, for the protection of commerce, in behalf of the United States, either with her Imperial Majesty in conjunction with other neutral Powers, or, if that shall be inadmissible, separately with her Imperial Majesty, or any of those, that is, those neutral Powers. The treaty being only made to continue during the war, his powers terminated with the war, or at most extended only to sign it with neutral Powers, and not to form a new separate treaty". Thereupon Congress adopted the following resolution: "Whereas, the primary object of the resolution of October 5,1780 , and of the commission and instructions to Mr. Dana relative to the accession of the United States to the neutral Confederacy, no longer can

\footnotetext{
${ }^{1}$ Wharton, Dip. Corr. of the Am. Rev., VI, 473.
} 
operate ... But inasmuch as the liberal principles on which the said confederacy was established are conceived to be, in general, favorable to the interests of nations, and particularly to those of the United States .... .

"Resolved, That the Ministers Plenipotentiary of these Unit. ed States for negotiating a peace be, and they are hereby, instructed, in case they should comprise in the definitive treaty any stipulation amounting to a recognition of the rights of neutral nations, to avoid accompanying them by any engagements which shall oblige the contracting parties to support those stipulations by arms". 2

From this resolution it appears that Congress was still warmly attached to the principles of the armed neutrality, although it seems that no representative of the United States was ever invited to sign a convention with any neutral nation incorporating them. But it is equally clear that Congress was anxious to avoid being implicated in the dynastic quarrels of European affairs.

The question was soon presented to the American representatives in Europe. John Adams wrote to Robert Livingston on July 7, 1783, less than a month after the above resolution had been adopted: "The Dutch ambassadors did once propose a meeting to us, and had it at my house. Dr. Franklin eame, but Mr. Jay did not, and Mr. Laurens was absent. The ambassadors desired to know whether we had power to enter into any engagements, provided France, Spain, and Holland should agree to any, in support of the armed neutrality. We showed them the resolution of Congress of the 5 of October, 1780, and told them thar Mr. Dana had been since vested with a particular commission to the same effect. We never heard anything further about it'. ${ }^{3}$

Thus the American revolutionary war ended without the

${ }^{2}$ Sparks, Dip. Corr., V, $500 \mathrm{ff}$.

${ }^{3}$ Sparks, Dip. Corr., IV, 45. 
principles of the armed neutrality having gained common recognition or become a part of international treaties except in rare cases. Apparently there seemed to be no specific need for adopting those principles after peace had once more been established. But the peace was not to endure very long for the revolutionary movements in France soon began to attract the attention of Europe, and developed so fast that on January 21, 1793, Louis XVI, perished by the guillotine. Only eleven days later France declared war on Great Britain and Holland. The progress of the French Revolution was followed with a great deal of interest both in the United States and Europe, and the old principles of the armed neutrality were again brought forth to protect the position of neutrals.

Gustavus III of Sweden planned to place himself at the head of a coalition against the revolutionary element in France in order to force them to re-establish the King on the throne. Spain, Russia, and Prussia were to co-operate with him, but the King of Sweden was to be the leader of the expedition. Spain, though interested, did not seem to have the courage of her conviction, and Catharine II, busy with her plans in Poland, was glad to see her neighbor absorbed in other directions and therefore tacitly consented to the plan without granting any effective assistance. The Swedish Ambassador Baron E. M. Stael von Holstein, who had represented his country at Paris since 1783, was recalled in December, 1791, and ordered not to return to Sweden because he had "become faithful to the French system". " But the assassination of Gustavus III quickly made 'a change in the entire alignment of nations.

One of the results of this change was that Dumaureiz decided to recall the French charge d'affairs in Stockholm, M. Gaussen, and "replaced him with a citizen who was completely in sym-

'S. J. Boethius, Gustaf $1 \mathrm{~V}$, Adolf formyndareregering och franska revolutionen, in Svensk Historisk Tidskrift (1887-8), VII-VIII, 109. 
pathy with the Revolution and not neglect to reap advantage of" what was called "the memorable catastrophe which in Swe. den seemed to give a new turn to the administration". 5 Both the new French ambassador, Verninac, and Baron Stael had a new convention between the two countries much at heart. Baror. Stael, contrary to orders from home, went to Sweden, and, through the aid of a friend Baron Karl Goran Bonde, succeeded in gaining access to the Prince Regent and won his personal favor. ${ }^{6}$ The news that France had conquered the Austrian Netherlands and the retreat of Prussia before Verninac started for Sweden, must have influenced the Swedish administration to a very large degree in its attitude toward France. Before the end of November, 1792, therefore, we find Baron Stael von Holstein started upon a diplomatic journey which had been agreed upon between the Prince Regent and M. Verninac ${ }^{7}$ to form a commercial treaty between the two countries. The plan was even enlarged so as to permit Denmark and Turkey to enter into it. But the war rolled on absorbing nation after nation in its currents.

Sweden, desirous of being neutral, decided to invite its neighbors to renew the armed neutrality, not without suggestions from France. Catharine II of Russia, having received England's sanction on the second partition of Poland, entered into an agree. ment with England on March 25, 1793, to renounce her former principles in regard to neutral commerce. She demanded that Sweden should follow her example, and when the Prince Regent refused she took that as an excuse for discontinuing her subsidies to Sweden, according to the Drottningholm declaration of $1791 .^{8}$

The correspondence is quoted by S. J. Boethius, Gustaf IV, Adolfs formyndareregering och franska revolutionen, in Svensk Historisk Tidskrift (1887-8), VII-VIII, $100 \mathrm{ff}$.

Ibid. 110.

Ibid. 178.

${ }^{8}$ S. J. Boethius, Gustaf IV Adolfs formyndareregering och franska revolutionen, in Svensk Historisk Tidskrift (1987-8), VII-VIII, 20 ; Hildebrand, Sveriges Historia VIII, 206. 
The mission of Baron Stael was so successful that he already in the spring of 1793 sent home a convention for the ratification of his home government. The French ambassador seemed certain that the convention should be ratified by the Swedish Government instantly, but on July 29,1793 , he was obliged to notify the French Government that the Prince Regent had not sent the expected courier with his ratification but instead an ordinary letter with some objections to the convention. The following are the main objections as stated by Verninac: 1) a few changes of which the principal one was that the "King of Sweden" is not mentioned enough, but the Swedish nation was mentioned in his place; 2) if France shortly after the signing of the convention insisted on the stipulated assistance, Sweden would be deprived of an essential part of her power, and become powerless against, Russia whose men-of-war already had entered the Baltic [France was to assist Sweden-in case she should be forced into war on account of the treaty-with 12,000 men infantry, 15 battleships, and 10 frigates; Sweden was to assist France with 8,000 men infantry, 10 battleships, and 6 frigates]. Therefore the Prince Regent insisted as a sine qua non upon a specific declaration that the Swedish troops should not be called farther away than they could come to her defense; and 3) the introduction did not sufficiently specify the fundamental principles on which the treaty was based: ${ }^{9}$ The French Government neglected to take up the suggestions of the Government of Sweden and therefore the de. fensive alliance of May 17, 1793, failed to be ratified, not on account of the Prince Regent, but on account of "the abstract revolutionary doctrines" whose principles were essentially opposed to the Swedish alliance. Robespierre had in the meantime replaced Danton both in the committee of public safety and in the committee on foreign affairs. ${ }^{10}$

'S. J. Boethius, Gustaf IV, Adolfs formyndareregering och franska revolutionen, in Svensk Historisk Tidskrift (1887:8), VII-VIII, 210.

${ }^{10}$ Ibid. 215. 
When this treaty failed the energetic Baron Stael advised that a new treaty should be prepared on the basis of the principles of the armed neutrality of 1780 . This suggestion was seconded by M. Verninac who was authorized to enter into negotiations in this regard. In the introduction to this treaty it was stated that "The French Republic and the King of Sweden desired to renew the almost two-century-long friendship betweer. the two peoples and energetically resist the domination of the allied powers over the neutrals'. The following principles werc included :

1. Sweden should resist all attempts of foreign powers to hinder the exercise of its rights to pursue its commerce in all commodities [Russia had already requested Sweden to notify France that no French ships could enter a Swedish port];

2. Sweden should protect its commerce by battleships;

3. Swedish merchant vessels should pay the same duty in France as French vessels;

4. France should remunerate Sweden for every battleship and frigate she armed for the protection of her commerce [Deforgues suggested in a letter that France would pay 500,000 and 300,000 franes respectively];

5. If the treaty should involve Sweden in war with Russia, France promised financial aid;

6. In order to aid Sweden in the first preparations, France promised, besides the subsidies, to pay a certain sum. of money when the treaty was signed, but the amount was not specified;

7. Sweden should not export any foodstuffs to enemies of the Republic so long as they persisted in taking neutral ships destined to France;

8. No foreign merchant should be allowed to accumulate and store foodstuffs to be shipped to enemies of France; 
9. French privateers should be allowed freely to sell their prizes in Sweden. ${ }^{11}$

Baron Stael promised to inform his government of the treaty, but he raised some objections to it: there were expressions in the introduction, regarding the allied governments, which were too much of a challenge to these powers; that article 9 , about the exports of foodstuffs, should cause a great deal of dissatisfaction in Sweden; that the amounts for battleships and frigates be specified at 500,000 and 300,000 l. respectively; that ten million 1. be decided on to be paid out when the treaty was signed, but Verni nac succeeded in reducing it to six million; finally Baron Stael requested that Sweden should be remunerated for convoys already fitted out. ${ }^{12}$

On October 9, the committee on Public Safety finally took up the remarks of Ambasador Stael for consideration and decided that no change should be made in the introduction; that convoy; should be remunerated by 500,000 and 300,000 respectively; that six millions should be paid when the treaty was signed. On October 12, Deforgues wrote to Verninac that the committee refused to change article 9. Verninac's despatch, dated November 15, stated that the Prince Regent approved the treaty except article 9, "because it would entirely destroy the commerce of Sweden and also make him appear inconsistent before all Europe".

The Prince Regent was, in fact, very well pleased with the turn of events in regard to France. Besides, the relation with Denmark had developed in a manner that suited the treaty of neutrality. During the last days of August or first days of September, he sent an envoy to Copenhagen to continue the work started

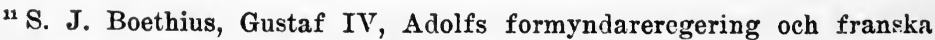
revolutionen, in Svensk Historisk Tidskrift (1887-8), VII, VIII, 216.

${ }^{12}$ S. J. Boethius, Op. Cit., VII-VIII, 218. 
by Baron Stael on his journey to France. ${ }^{13}$ But even this alliance with France came to naught.

It has been considered necessary to give a discussion on the relation of Sweden with certain European nations in order to obtain the proper angle from which to view the relations with the United States. It must further be remembered that the United States and Sweden had not as yet exchanged public min isters and therefore their relations were carried on through representatives of the two countries who met in some other European capital, or by similar indirect means.

Neither Verninac nor Stael could console themselves with the failure of the treaty of 1793 and therefore they proceeded energetically each in his own way to discover some other plan. Verninac proposed to the Committee on Public Safety that a secret agreement should be made between France and Sweden, and that Sweden should be requested to send out eight ships of the line and four frigates in May, 1794, or earlier; and that negotiations should be started with Sweden, Denmark, Turkey, Po. land, Venice, Genoa, and the United States to form "a league and receive subsidies or commercial advantages" from France. Sweden and Denmark should be considered as allies of France and they should each receive 6 million l. when the convention would be signed and 500,000 1. for every ship of the line and 300,000 l. for each frigate. ${ }^{14}$

Baron Stael, on the other hand, was recalled when he failed to make a satisfactory treaty with France. On his way to Sweden he stopped at Copenhagen where he was preceded by another Swedish envoy Baron E_- There he worked energetically to obtain a new treaty of armed neutrality with Denmark. The Prince Regent was rather reluctant in giving him the necessary

${ }^{13}$ S. J. Boethius, Op. Cit., VII-VIII, 220.

${ }^{14}$ Quoted by S. J. Boethius, in Svensk Historisk Tidskrift (1887-8), VII-VIII, 224. 
authority but finally he wrote that Stael's arguments "weighed so heavily" that the Prince Regent through a letter from Sparre, the chancellor, dated March 31, authorized Stael, "if it was considered necessary" to sign a convention without further instructions. Accordingly the convention was signed in Copenhagen on March 27, 1794. ${ }^{15}$ With this treaty Stael set out for Sweden, and both countries shortly afterward ratified it.

Baron Stael did not, however, long remain in Sweden, but returned to France, ostensibly on account of the death of his mother-in-law, but really to attempt to receive the French subsidies promised in reward for the armed neutrality. On his way he stopped in Copenhagen, partly because of a temporary illness, and partly to await authorization from the Prince Regent to recognize the Republic and the appointment as ambassador to France, which powers he proposed to use in order to influence the French authorities. On January 9, 1795, he arrived at Basel, where he met Signeul ${ }^{16}$ who brought good news from Paris. Signeul thought that the authorities at Paris would be willing to reward Sweden for her expenses in connection with the armed neutrality. Baron Stael, encouraged by the information he reccived concerning the general political conditions, hastened to Paris, ${ }^{17}$ and also urged his home government to increase the convoys in lieu of French aid.

The Prince Regent did not, however, authorize the recognition of the French Republic until after the subsidy convention had been signed; but the Swedish Government did approach the Government of Denmark with the proposal to increase the convoys. The Danish Government was not inclined to accept this 226.

${ }^{15}$ See S. J. Boethius, in Svensk Historisk Tidskrift (1887-8), VII-VIII,

${ }^{16}$ Signeul was the Swedish courier who carried many of these documents from Stael to Sweden.

${ }^{17} \mathrm{~S}$. J. Boethius discusses this question fully, in Svensk Historisk Tirlskrift (1889-90), IX-X, 5 ff. 
proposal. The Danish Prime Minister even went so far as to inform the Swedish envoy at his Court that the propositions of Sweden were occasioned by the necessity to support its recognition of the French Republic and therefore of no concern to Denmark. The result of this interview was that the Swedish chancellor in a letter to Stael "renewed, but not in any way changed" his instructions; and the Prince Regent wrote to the Danish Crown Prince on April 27, requesting a more energetic participation in the armed neutrality.

It seems that this letter had the desired effect for the Prince Regent, with the Swedish Crown Prince on May 19, went to Skane with a view to meet the Danish Crown Prince to strengthen the union by a personal interview. Shortly before the royal party started from Stockholm a notice was received that Denmark had decided to enter more energetically into the participation in the armed neutrality. Bernstorff even tried to explain away his statement to the Swedish envoy. ${ }^{18}$

Not until September 14, 1795, did Baron Stael succeed in bringing his negotiations in Paris to a close. The result was the establishment of a "secret and preliminary" convention which contained the following provisions:

1. In view of a definitive treaty of commerce and alliance, Sweden agreed to fit out 10 ships of the line and 5 frigates ;

2. When this fleet set out, Sweden should notify England and other powers hostile to the Republic that she had decided to enforce her neutral rights;

3. Sweden should demand immediate reparation or remuncration from England for vessels and cargoes taken;

4. If Sweden, on account of this demand or on account of retaliatory measures, should be involved in war with

${ }^{18}$ Quoted by S. J. Boethius in Svensk Historisk Tidskrift (1889-90), IX-X, 14, 23. 
England, Russia, or any other power, France would pay Sweden 400,000 1. for every ship of the line and 200,000 1. for each frigate;

5. France should give to Sweden one-tenth of the value of the cargoes which she could retake for France;

6. These cargoes should immediately with the deduction of one-tenth be given to France or their French owners ;

7. Sweden should with all her might and in co-operation with France and Holland exert her influence upon Denmark to participate in the freedom of the seas;

8. On account of the cost of arming her convoys which Sweden ever since the beginning of the war had made in order to maintain her neutrality, and to prove her interest and friendship, France should pay Sweden ten million 1. namely four million when the convention was ratified and one million every six months from January 1, 1796, until the whole sum was paid;

9. If Sweden and France were drawn into a common war, neither one should have a separate peace. ${ }^{19}$

The convention of September 14, 1795, was only preliminary and should be exchanged as soon as possible for a definitive treaty of commerce and defensive alliance for which the treaties of 1741,1781 , and 1787 should serve as types. The convention between Sweden, Denmark and France should be enlarged to a confederation of all the neutrals so as to include Prussia, Holland, Spain, Portugal, United States, and Venice. ${ }^{2 n}$

${ }^{19}$ Quoterl by S. J. Boethius, in Svensk Historisk Tidskrift (1889-90), IX-X, 37: This time the Prince Regent became fairly well satisfied and ou October 2, the chancellor, Sparre, notified Baron Stael of the ratification, but France never sent the counter ratification of the convention of September 14, 1795. See ibid., 307.

${ }^{20}$ Sparre to Stael, October 2, 9 and December 15, 1795; also quoted by S. J. Boethius, in Svensk Historisk Tidskrift (1889-90), IX-X, 277. 
In the meantime attempts had been made to enlarge the confederation of neutrals. On April 28, 1794, the Swedish Minister in London, Lars Engestrom, informed Thomas Pinck. ney, the American Minister at that court, that he had received instructions to invite the United States to accede to it, and communicated a copy of the convention. ${ }^{21}$ Pinckney seemed greatly pleased and he communicated the message to his home Government.

Whether the authorities in the United States had received any official information about the formation of a league of northern powers to enforce the right of neutrals is doubtful. The fact is, however, that the question received some attention in the instructions for John Jay when he was sent to negotiate a treaty with England. Edmund Randolph, who had replaced Jefferson as Secretary of.State, wrote: "You will have no diffculty in gaining access to the ministers of Prussia, Denmark, and Sweden at the Court of London. The principles of armed neutrality would abundantly cover our neutral rights. If, therefore, the situation of things with respect to Great Britain should dictate the necessity of taking the precaution of foreign co-operation upon this head; if no prospect of accomodation should be thwarted by the danger of such a measure being known to the British Court; and if an entire view of all our political relations, shall, in your judgment, permit the step, you will sound those ministers upon the probability of an alliance with their nations to support those principles'". ${ }^{22}$

A few days later Mr. Randolph wrote to John Jay in a letter: "If it were not to demonstrate our anxiety for the success of your mission, it would be scarcely worth mentioning a circumstance which you will doubtless have ascertained before

${ }^{21}$ Engestrom to Sparre, April 29, 1794; Engestrom had formerly been Minister to Poland.

${ }^{22}$ Instructions to John Jay, May 6, 1794, Am. State Papers, Foreig. Affairs, I, 473. 
that part of your instructions relative to Sweden is executed. . .... The President, reviewing the possibilities which are opened by the prospect of what you already know, and what will now be communicated to you, becomes daily more strenuous that Denmark and Sweden shall be well understood, as to the point to which they will go with us in case we are driven into a war with Great Britain. He would send a minister thither immediately to explore and negotiate eventually; but that good faith and the state of things in your hands, require the suspension of this measure, and he confides that you will, if necessary, prepare the minds of those powers, through their representatives in London, and give us the earliest notice of the fitness of making a more direct and formal application to them'. ${ }^{23}$ In keeping with these instructions Mr. Jay seems to have been intimate with the Danish and Swedish ministers at London, ${ }^{24}$ but no definite results followed.

In the correspondence of James Monroe who at this time was in France, there is some further information on this subject. On October 16, 1794, he wrote: "Denmark and Sweden, offended at the unlawful restraint imposed by her [England] on their trade in the arbitrary rule of contraband, have..... united their fleet to the amount of about thirty sails, for the purpose of vindicating their rights', ${ }^{25}$ But it is evident that more direct suggestions had been made earlier for on March 8, 1795, the Secretary of State wrote to him in the following words: "However, your idea as to Denmark and Sweden, though it was always attended to, grows of less importance. I shall not

${ }^{28}$ Randolph to Jay, May 27, 1794; Am. State Papers, For. Rel., I, 474.

${ }^{24} \mathrm{Mr}$. S. M. Bemis has written a very interesting article in the Am. Historical Review touching upon this phase of the Jay Treaty. (Am. His. torical Review, October, 1918).

${ }^{25}$ Monroe to Randolph, October 16; December 2, 1794; Am. State Papers, For. Rel., I, 92 ; Monroe, A View of the Conduct of the Executive of the United States, 46. 
now answer your proposition, or rather intimation, relative to a certain concert, until a future opportunity, and after hearing further from you concerning it. You will have concluded from my letter, that the step is viewed here as a very strong one". ${ }^{28}$ Only a month later the Secretary of State wrote again to Monroe: "The dispatches which you are understood to have intrusted to Mr. Smith, of this city, not having yet arrived, our anxiety continues to learn the issue of the concert of which you have suggested. You will have been informed by my letter of the 8th ultimo that the step is viewed here as a strong one; and, notwithstanding the rapid successes which have attended ihe arms of our ally, we sreadily direct our course to the character of neutrality which we profess, and, therefore, the more it is examined the stronger it appears. You will hear from me shortly, in a more particular manner, concerning it, and the style in which our negotiation at Paris, ought, in our judgment, to be observed. But I must be permitted to remark, that the invariable policy of the President is, to be as independent as possible, of every nation upon earth; and this policy is not assumed now for the first time, when, perhaps, it may be insidiously preached by some, who lean to Great Britain, to preveut a tendency to France; but it is wise at all times, and, if steadily pursued, will protect our country from the effects of the commotion in Europe"'. 27

In June, Monroe renewed his proposition of alliance with the Northern Powers and suggested the addition of. Spain to Sweden, Denmark, France, and Holland. If proper arguments, based on these facts, would be used on Great Britain, they ought to produce an "amicable policy". If the contrary should

${ }^{26}$ Randolph to Monroe, March 8, 1795, Am. State Papers, For. Rel., I, 699 ; Monroe, A View of the Conduct of the Executive of the United States, 157.

${ }^{27}$ Randolph to Monroe, April 7, 1795, Am. State Papers, For. Rel., I, 701. 
happen, however, he would deem it his duty "immediately to advise you of it, by a vessel (in case none other offers) to be dispatched for the purpose". ${ }^{28}$ What part it should become the United States to assume, if these measures failed, belonged, in his opinion, to some one else to determine.

About a week later Monroe reported a conversation he had had with the Swedish Ambassador at Paris in the following language: "In conversation a few days past with Baron Stahl [Stael], Ambassador from Sweden, he informed me of a communication formerly made by the Court of Sweden to Mr. Pinckney at London, for our government, and upon which no answer was given, although it was much wished. I desired his communication in writing that I might forward it to you, and which was accordingly given, and is herewith transmitted. I have no doubt that whatever he says to me is known to the committee, as I was informed by some of its members in the beginning of the winter, and before the Baron arrived, that such an application had been made to us from that quarter. It belongs to me only to forward this paper, and which I do, not doubting that I shall be instructed, relative thereto, in the most suitable manner', ${ }^{29}$

A few years later John Q. Adams wrote about the same question while he was minister to Prussia, saying that "the present. Swedish minister here is the person who in the year 1793 [1794] delivered to Pinckney certain propositions which he then forwarded to our government, the object of which was a certain concert for the support of neutral rights. $\mathrm{He}$ has mentioned this fact to me, and added that no answer had ever

${ }^{28}$ Monroe to the Secretary of State, June 26, 1795, Am. State Papers, For. Rel., I, 715; Monroe, A View of the Conduct of the Executive of the United States, 178.

${ }^{29}$ Monroe to the Secretary of State, July 6, 1795; Am. State Papers, For. Rel., I, 719; Monroe, A View of the Conduct of the Executive of the United States, 329 . 
been received to his proposals. I have heard at various times the same observation from other Swedish diplomatic characters, and I find the thing noticed in Mr. Monroe's book".

"The omission of an answer, I am confident, was felt, and I fear still is felt by the Swedish government". ${ }^{30}$

Monroe did, however, receive the notice that both his communication as well as that of Pinckney had been received, but he received no instructions to answer Baron Stael in any way. Pickering, who succeeded Randolph as Secretary of State, August 20, sent the following reply to Monroe: .... "This serves merely to acknowledge the receipt (on the 7 instant) of your letter of the 4 (6th) of July with its inclosure.

"The President is at Mount Vernon. This forbids me saying anything on the subject of Baron Stahl's [Stael] application. Besides, I do not conceive that the Executive could even attempt to negotiate about it until Congress should provide the means of rendering an agreement efficient. The proposition with a copy of the convention between Sweden and Denmark I find were transmitted from London by Mr. Pinckney in his letter of the 8 of last May; it does not appear when they were received at this office". ${ }^{31}$ In regard to the joining of the convention between Denmark and Sweden of March 27, 1794, "for the maintenance of the rights of neutral navigation", President Washington submitted the question to his cabinet in July 1794. Randolph was in favor of it, Hamilton, Knox, and Bradford against it. Knox in his answer said in part: "There may be a state of things operating upon Denmark and Sweden, essentially different from that operating in America. States as well as individuals often have secret motives for their conduct. I dread being linked in with the follies or vices of European Powers.. ......". ${ }^{32}$

${ }^{30}$ Writings of John Q. Adams, (Ford, ed.), II, 303.

${ }^{31}$ Writings of James Monroe, (S. M. Hamilton, ed.) II, 329.

${ }^{32}$ Quoted in Writings of James Monroe, II, 329. 
In the main the armed neitrality of 1794 was a failure principally on account of the diplomacy of Great Britain which resulted in the agreement with Russia for the division of Poland, and on account of the Jay Treaty. This left the northern combination too feeble to enforce their rights and effectively protect their commerce.

The treaty between the United States and Sweden as well as that with Prussia, was about to expire. In order to undertake the work of renewing these treaties John Quincy Adams was transferred to Berlin. ${ }^{33}$ There he met the Swedish minister and began the work. The instructions which Adams received from home requested him to abandon the principle "that free ships make free goods'". ${ }^{34}$ In regard to this omission Mr. Pickering, the Secretary of State, made the following explanation: "The principle is peculiarly interesting to us, because our naval concerns are mercantile and not war-like; and you will readily pereeive that the abandonment of that principle was suggested by the measures of the belligerent powers, during the present war, in which we have found that neither its obligations by the pretended law of nations, nor the solemn stipulations of treaties, secured its observation; on the contrary, it has been made the sport of events'". ${ }^{35}$ The following March the Secretary of State again had occasion to revert to this subject in a letter to $\mathrm{Mr}$. Adams. He said: "As the war continues and it now seems scarcely possible for the United States not to become a party in it, you will doubtless be determined by your instructions of the 15th and 17th of July last, in renewing our treaties with Prussia and Sweden, and reject the article in each which stipulates that free ships shall make free goods..... The Swedish and Prussian commerce will then be only on the footing of the

${ }^{33}$ Memoirs of John Q. Adams (C. F. Adams, ed.), I, 199.

${ }^{34}$ Am. State Papers, For. Rel., II, 250.

${ }^{35}$ Pickering to Adams, July 17, 1797; Am. State Papers, For Rel., II. 250. 
commerce of Denmark, with whom we have no treaty;..... ${ }^{\text {se }}$ But Adams answered that although he would be guided by the instructions, he had recently written that in his opinion the alteration would be inexpedient. The reason he gave for this opinion was that "Sweden and Prussia are both strongly attached to the principle of making the ships protect the eargo. They have more than once contended that such is the rule even by the ordinary laws of nations". "ar But in November of the same year the Prussian Minister wrote to Mr. Adams that the principle of free ships makes the merchandise frce had "not been sufficiently respected during the two last wars, and especially in that which is now carried on; and that contradictory dispositions of the principal belligerent Powers not permitting, at present time, a satisfactory adjustment of the litigated question...." "s8

The Swedish minister at Berlin with whom John Q. Adams started negotiations for the renewal of the treaty soon afterwards took ill with a disease that caused his death, and some time elapsed before his successor was appointed wherefore "the treaty was suffered to expire",. ${ }^{39}$

United States had also agreed to the Jay treaty without any provision as to the freedom of cargo on free ships, wherefore the British interests triumphed over the principles of international law advocated by the neutral nations.

After the close of the war, Congress, by an act of March 3, 1815 , made a proposal to all maritime nations to lay aside "the system of retaliatory restrictions and exclusions", and to place the shipping of both parties to the common trade, "on a footing of equality, in respect to the duties of tonnage and imports". This offer was accepted only by Great Britain and Sweden. ${ }^{40}$

${ }^{\text {an }}$ Am. State Papers, For. Rel., II, 251.

${ }^{37}$ Am. State Papers, For. Rel., II, 252.

${ }^{38}$ Annals of Congress, 6 session, p. 1235.

${ }^{\text {3 }}$ Memoirs of John Q. Adams (C. F. Adams, ed.), I, 199.

${ }^{40} \mathrm{~J}$. Q. Adams, Message to Congress, December 6, 1825; 19 Congress, 1 sess., Senate Doc., 2, p. 4. 
Not until 1856, at a meeting of plenipotentiaries in Paris, was the principle free ships, free goods, renewed, together with three additional principles:

1. Privateering is, and remains abolished;

2. Neutral flag covers enemy's goods with exception of contraband of war;

3. Neutral goods with the exception of contraband of war, are not liable to capture under enemy's flag;

4. "Blockades, in order to be binding, must be effective; that is to say, maintained by a force sufficient really to prevent access to the coast of the enemy'. ${ }^{41}$

This proposal failed to be adopted by the nations and although the conference of London in 1909 renewed the recommendation, the world war came on without these principles having been recognized as a part of the law of nations.

${ }^{41}$ Senate Doc., 104; 34 Congress, 1 sess., XVI. 


\section{CHAPTER III}

\section{The Stralsund Claims}

At the treaty of Tilsit in 1807, Napoleon and Alexander I of Russia decided between themselves what to do with the rest of the world, and especially with Sweden. Alexander took this step without consulting Sweden regardless of the fact that he had entered into a military convention with Prussia that "they should agree between themselves and with the King of Sweden regarding the steps ... to be taken to obtain safety'". In direct, disregard of these stipulations Russia and Prussia entered into an agreement with Napoleon regarding both armistice and peace without consulting Sweden. ${ }^{1}$ From a study of the correspoudence of the leading characters it seems fairly certain that Prussia wished to keep the King of Sweden uninformed about the agreement in order to assert her ambition of leadership in northern Germany, "which aroused the liveliest uneasiness both in London and Vienna". ${ }^{2}$ The plan of Alexander seems to have been to advance the interest of Russia by offering Napoleon an alliance against England. To be sure Russia promised to become the mediator between England and France, but the lines along which this was to be done were clearly drawn and contained two mair. principles :

1. The flags of all states were to have similar and complete freedom of the seas;

${ }^{1}$ Grade, Sverige och Tilsit Alliansen, 12.

${ }^{2}$ Grade, Op. Cit., 14. 
$2 . \quad$ The French territory and colonies conquered since 1805 should be restored. If England should refuse to accep: this offer, all harbors in Germany were to be closed to the commerce of England. ${ }^{3}$

In regard to Sweden it was stated that Russia ought to conquer Finland in order to relieve the "beautiful ladies of Petersburg" from "hearing the Swedish cannons". Nothing specific seems to have been said regarding Finland in the negotiations at Tilsit; only the traité d'alliance has a direct reference to Sweden, and it specifies that the contracting parties should together and simultaneously request the three courts at "Copenhagen, Stockholm, and Lisbon to close their ports to English commerce, recall their envoys from London, and declare war on England'. If any of the three courts should refuse, that one should be treated as an enemy by the contracting parties; and if Sweden should refuse, Denmark should be forced to declare war on it. ${ }^{4}$ After Tilsit, therefore, it became impossible for Sweden to remain neutral; war was imperative, and the remaining question was, should the war be waged against England or against France. Since Sweden refused to negotiate for peace with Napoleon, Russia was bound by treaty to declare war against Sweden on land and sea.

It appears that Alexander, brother-in-law of the King of Sweden, had promised Napoleon that he would inform Gustavus IV regarding the condition of this relation, ${ }^{5}$ but, although Alexander met the Swedish envoy in Prussia at least four times after the arrangement had been made, there seems to have been no attempt on his part to inform his former ally of the change. Russia had even promised to force the King of Sweden to negotiate for peace with Napoleon, ${ }^{6}$ which Sweden least of all desired.

${ }^{3}$ Grade, Sverige och Tilsit Alliansen, 29; and sources there cited.

${ }^{4}$ Traite de paix, Art. 5.

${ }^{5}$ Brinchman, dispatch to Memiel, July 15, 1807.

${ }^{6}$ Grade, Op. Cit., 66 and sources cited there. 
But Napoleon wished it clearly understood that he had no plans against Swedish Pomerania, nor did he require that the Swedish monarch should recognize him as Emperor of France. ${ }^{7}$

When Alexander notified Gustavus IV about the peace, he failed to express the interest of Sweden in regard to the peace, nor did he make any attempt to explain to the King of Sweden whether he made the views of Sweden known to Napoleon or not, nor did he notify his relative about the attempt to offer England peace. These facts make it appear as if Russia had no objections to the continuance of the struggle between Napoleon and Sweden. ${ }^{8}$

On September 14, 1807, Napoleon dictated instructions to his minister of foreign affairs for Savary, his minister in Russia, in which he stated that Sweden ought to unite with France and Russia to defend the "freedom of the Baltic." Already on Au. gust 26 Napoleon had mentioned this fact to Alexander, asking what he intended to do in order to aid Denmark against an English attack and to force the King of Sweden to join with them in "his truest interest, the freedom of the Baltic". " He added: "At any rate your Majesty may count on me. I have an army in Hamburg. With interest I await information from your Majesty regarding these events', Napoleon expressed his thought even more clearly to his representative in Petrograd, General Savary: "I think that Russia ought to send an army against Sweden to force her to unite with Denmark. The Emperor need only tell me what is necessary; I have a considerable army at Hamburg". ${ }^{10}$

The instructions on September 14, 1807, seem to have been designed to explain the secret Tilsit alliance. According to this, the action against Sweden should have three parts: Alexander I

' Ohampagny to Savary, Rambouillet, September 14, 1807.

${ }^{8}$ Grade, Op. Cit., 68.

- Saint Cloud, August 26, Corresp., XV, 13078.

${ }^{10}$ Saint Cloud, August 26, Ccrresp., XV, 13079. 
ought to try by persuasion to make his brother-in-law change his policy; if this failed, Russia should occupy Finland, and France together with Denmark should threaten Sweden from the west; should this plan also fail, Sweden must be "forced to do its duty", and that work would devolve on Russia. ${ }^{11}$ The whole plan of Napoleon is permeated with a desire to reach an understanding with Sweden without dismembering the country, for, although Russia was authorized to occupy Finland, there was no permission to conquer it. The threat to occupy Finland was only a means to force Sweden to accept the continental system. Na poleon wrote with that idea in view November 1, in the following words: "If Russia declares war on Sweden, Denmark will do the same, and a Danish army will attack her at the same time'". ${ }^{12}$

On November 16, Napoleon set out on a trip to Italy and while on this trip he received the information that Alexander had declared war against England. This was but a step to a war with Sweden. Napoleon wrote to the Tsar : "I am very much pleased to see the work of Tilsit develop. Of all the countries on the continent Sweden alone lives in peace with England; Your Majesty will presumably adjust the matter',. ${ }^{13}$

Alexander adjusted his relation to Sweden in his own way. On October 7, the envoys of Sweden and Denmark received identical notes in which the Tsar alluded to the conventions of 1780 and 1800 between the northern powers to close the Baltic, and expressed a desire to hear what attitude the courts of Sweden and Denmark had decided to assume regarding the action of Great Britain in bombarding Copenhagen. The Tsar sympathized with Denmark, but he had seemingly no enmity to England. As a proof of the friendly attitude toward England it was

${ }^{11}$ Grade, Sverige och Tilsit Alliansen, 84, where a full discussion of these problems is given.

${ }^{12}$ Napoleon to Champagny, Fontainbleau, November 1, 1807. 13383.

${ }^{13}$ Napoleon to Alexander, Venice, December 7, 1807, Corresp., XVI, 
mentioned that no Russian port had been closed against English commerce while those of Prussia had.

Gustavus IV sought in vain for a reasonable ground of explanation of the action of the Russian Government, and he found. no other than to place it in connection with the secret agreement, which he had every reason to suppose had been adopted at Tilsit. Gustavus IV then adopted the explanation that the Tsar had promised Napoleon that he would try to force all the powers of the Baltic to close their ports against England. Dr. Grade asks : "could the proposal to renew the conventions of 1780 and 1800 very well have been a veiled scheme of which use was made in order to have a pretext for war'". ${ }^{14} \mathrm{He}$ answers the question in the negative. But Russia broke with England and besides proclaimed the principles of the armed neutrality. ${ }^{15}$

November 13, the Swedish minister in Petrograd had an interview with Alexander I and delivered a letter from his King. At that interview the ambassador expressed a fear in regard to the movement of troops toward Finland and asked for some positive statement in regard to the aims of the Emperor. Alexander assured him that it was nothing but a safety measure, and that he wished his troops at hand in case of need; that he had no tastes for territorial expansion; and that the rocks of Finland were not in the least tempting to him. ${ }^{16}$

The following day, November 14, the Emperor had a meeting with the French Ambassador and at this meeting it is reported that Alexander said: "I had a long conversation with him [Swedish minister], and I demanded of him emphatically that he should give his court the advice to approach France quickly, while I showed the danger in which a small country like Sweden

${ }^{14}$ Grade, Sverige och Tilsit Alliansen, 109.

${ }^{15}$ Grade, Op. Cit., 123.

${ }^{16}$ Quoted in Grade, Sverige och Tilsit Alliansen, 132, 
was placed by not accepting the common cause'". ${ }^{17}$ But this reference to the conference with the Swedish minister was decidedly erroneous for it gave the opposite point of view from beginning to end. The reasons for this duplicity on the part of Russia are stated by Dr. Grade as a desire not to impart any fear into the Court of Sweden, and to relieve himself from any further pressure from the French ambassador. ${ }^{18}$

The Danish minister soon afterward reported a conference he had had with the Russian minister of foreign affairs at which the whole line of procedure was outlined. If the answer from the Swedish monarch was unsatisfactory, Denmark should attack Skane and Russia should simultaneously attack Finland. But when the Swedish minister had a meeting with the minister of foreign affairs, he was assured most emphatically that the Emperor had no hostile plans against Sweden, but, on the contrary, that he wished that he could prove his high regard and friendship. ${ }^{19}$ At this meeting the Swedish minister suggested the ncutrality of Sweden in view of eventual conflicts on the continent, if England refrained from entering the Baltic.

The above analysis has been considered necessary in order to show that all of northern Europe with the exception of Sweden was included in the continental system. The ports that were not closed by the continental system were closed by the English blockade. Some of the American merchants were also very much in. terested in the commerce with Sweden. Stephen Girard was one of them and he had his agents everywhere and his vessels were exposed to violent treatment. His agents wrote that there were about one hundred American vessels at Gothenburg. The supercargoes of some of these vessels seeing the complication in the

\footnotetext{
83 , p. 227 f.

${ }^{17}$ Sbornik, Imperatorskago Russkago Istcritcheskago Obstchestva, vol.

${ }^{18}$ Grade, Sverige och Tilsit Alliansen, 135.

${ }^{10}$ Stedingk, Posthumus Memoirs, II, 392.
} 
polities of Europe, and not knowing what to do, hastened to Hamburg to investigate what could be done there. ${ }^{20}$

About this time the Rosseau, a vessel belonging to Stephen Girard, was sent to Stralsund in Swedish Pomerania, and then ordered in ballast to Russia. One of Girard's agents, Mr. Hutch. inson, wrote that he was undecided as to what to do when on May 25 he heard of the decree of Rambouillet and hurried to Stralsund "to accelerate if possible the sale" of the property and the departure of the ships before "the French consul" should be sent to that place to enforce the decree against the commerce of the United States. ${ }^{21}$ Mr. Hutchinson, however, arrived too late, and about 530 bales of cotton on the ship were sequestered "together with all other American property at Stralsund". 22

Although the American Government could not offer effective relief to its merchants, Congress adopted a resolution on January 3,1810 , requesting the President to lay before the "House any information he may possess relative to the blockade of the ports of the Baltic by France, and the exclusion of neutral vessels by Russia, Sweden and Denmark". ${ }^{23}$ On January 12 the answer was reported "that no information" had been received at the Department of State relative to the blockade of the ports of the Baltic. But this answer was accompanied by the translation of an "Ukase" of the Russian Government, dated May 14, 1809, and a translation of instruction given to the privateers of Denmark on September 14, 1807, but no documentary charge was made against Sweden. ${ }^{24}$ In view of the fact that so little information was available on the Baltic situation the House adopted a resolu-

${ }^{20}$ McMaster, Life and Times of Stephen Girard, II, 125.

${ }^{21}$ McMaster, Life and Times of Stephen Girard, II, 124.

${ }^{22}$ McMaster, Op. Cit., II, 125.

${ }^{23}$ House Journal, 11 Cong. 1 sess., 155; State Papers and Public Documents, VII, 342.

${ }^{24}$ Am. State Papers, For. Rel., III, 327; State Papers and Public Douuments, VII, 342 . 
tion on April 9, 1810, “That the Committee on Foreign Relations be discharged from the consideration of the message from the President of the United States of the twelfth of January last, communicating information relative to the blockade of the Baltic by France, and the exclusion of neutral vessels by Russia, Sweden, and Denmark',. ${ }^{25}$

The facts were that the British had blockaded the Sound, so that all vessels must pass through the Belt in order to enter tha Baltic; ${ }^{26}$ and a French privateer, "La Minute No. 2", was cruising off Helsingör just outside the Danish jurisdiction. This privateer did a great deal of injury to the Swedish commerce and therefore the Swedish Government captured it and held the sailors as captives. ${ }^{27}$ At first Napoleon paid no attention to this act, but later he sent his army into Swedish Pomerania to eapture that Province and gave as his excuse the fact that Sweden had captured his privateer.

So far the United States had no diplomatic representative but only consular representation in Sweden. The Swedish Government was, however, much interested in having a minister or chargé d'affairs from the United States to "maintain and extend friendly relations and commercial intercourse". The Swedish. Government was prepared to receive such a representative and had already designated a person for that mission. ${ }^{28}$ The man who was "designated" for the mission to the United States was Mr. Kantzow, who had returned from Brazil a short time before, where he had resided as chargé d'affairs for several years. Before Mr. Kantzow was sent to Brazil he had served as consul general of Sweden in Portugal. Mr. Kantzow refused to go as chargé d'affairs, but he consented to go as minister. The United States consul in Sweden, John Speyer, wrote about him in the following

${ }^{25}$ House Journal, 11 Cong. 1 sess., (1809-1810), 353.

${ }^{26}$ McMaster, Life and Times of Stephen Girard, II, 125.

${ }^{27}$ Am. State Papers, For. Rel., III, 559.

${ }^{28}$ Am. State Papers, For, Rel., III, 619. 
words: "From the personal knowledge I have of Mr. Kantzow, I think him well calculated to contribute to the good understanding of our respective Governments." 29 On the 24 of March following, the Minister of Foreign Affairs notified Mr. Speyer that Mr. Kantzow had been appointed, and he, accompanied by his family, would leave for England on his way to the United States early in May. But for some reason Mr. Kantzow did not start on his mission until August 15, 1812. When he left Sweden, the Prince Regent directed him to represent to the English Government the desire of Sweden "to see a good understanding restored with the United States". In reporting the above fact the consul said: "as this Government expects the appointment of a minister or a chargé de'affairs, in return for Mr. Kantzow's mission, I have not presented the commission as consul for this place. I am apprehensive it might be ungraciously received here after their notification of the appointment of a minister'. ${ }^{30}$ When President Madison, therefore, referred to foreign relation in his message of November 4, 1812, he could truthfully say: "Sweden also professes sentiments favorable to the subsisting harmony". 31

During those war-torn times it was important for any nation to treat its friends with consideration. The Commissioner of prisoners in London, Mr. Beasley, reported to the Secretary of State: "Notwithstanding the present apparent irrelation of the Swedish Government, I have been assured by Mr. de Kantzow, and I learn from other sources that it has invariably manifested the most friendly disposition towards the United States. Those American vessels which have sought shelter in its ports have experienced perfect protection. British cruisers are not allowed,

20 John Speyer to Secretary of State, January 21, 1812, Am. State Pa. pers, For. Rel., III, 619 ; Annals of Congress, 13 Cong., 1 sess., I, 94.

${ }^{30}$ Am. State Papers, For. Rel., III, 619 ; Annals of Congress, 13 Cong.. 1 sess., I, 94.

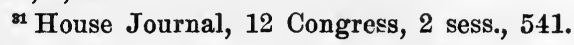


within its territories, to dispose of the prizes they take from the United States; and, in some instances, the protection of Swedish convoy has been afforded to American vessels passing through the Sound". ${ }^{32}$ This circumstance was mentioned to Mr. Kantzow by Lord Castlereagh "with no satisfaction". Mr. Beasley added three reasons why a minister ought to be appointed to Sweden. In the first place, he feared that the "intrigue of our enemy" would, if not speedily counteracted, produce a state of things decidedly unfriendly. Secondly, the jealousy between Sweden and Denmark, long existing, had, it was stated, contributed greatly to the feeling which had given rise to this mission. Thirdly, "the result of all the American property now in the dominions of Sweden will depend on the course which the Government of the United States may pursue on this critical and delicate emergency". ${ }^{33}$

It was, however, not before May 31, 1813, that President Madison nominated a minister to Sweden. His choice fell upon Jonathan Russell, who was chargé d'affairs at London when he was nominated. ${ }^{34}$ Now followed an investigation of the official conduct of the minister nominated and the following resolution was adopted: "That the President of the United States be requested to inform the Senate whether any communication has been received from Jonathan Russell admitting or denying the declaration of the Duke of Bassano to Mr. Barlow, that he informed his predecessor of the repeal of the Berlin and Milan decrees at the date of that decree". In addition the Senate called upon the President for any "correspondence which may have passed between the United States and the King of Sweden, re specting the interchange of public ministers between the two Gov-

${ }^{32}$ Am. State Papers, For. Rel., III, 618; Annals of Congress, 13 Cong.: 1 sess., 93.

${ }^{23}$ Annals of Congress, 13 Cong., 1 sess., 93; Am. State Papers, For. Rel., III, 618.

${ }^{34}$ Am. State Papers, For. Rel., III, 618. 
ernments". ${ }^{35}$ Five days later, June 7, 1813, the President submitted the answer which was that "no direct correspondence has taken place on the subject." But several extracts of letters from Mr. Speyer together with a letter from Mr. Beasley regarding the wishes of the Swedish Government in that regard were sub. mitted. ${ }^{36}$

On the same day Mr. Goldsborough of the committee to whom the nomination of Jonathan Russell was referred, reported "That, in pursuance of the orders of the Senate, the committee met the Secretary of State by appointment at the office of the Department of State, when they were informed by the Secretary that there was no official denial or admission of Mr. Jonathan Russell, that the allegation of the Duke of Bassano to Mr. Barlow, referred to, was true; but that he [the Secretary] had a private letter from Mr. Russell subsequent to the allegation of the Duke of Bassano, in which he understood the allegation to be unequivocally denied". ${ }^{37}$ On motion it was decided that further consideration of the nomination should be postponed. Then Mr. Goldsborough submitted the following resolution: "That it is inexpedient at this time to send a Minister Plenipoteniary to Swe. den".

Four days later, however, the Senate "resumed the consideration of the nomination of Jonathan Russell together with the motion of Mr. Goldsborough thereon of the 7 instant". ${ }^{38}$ The whole question was again referred to a committee "to enquire and report thereon". After some debate it was agreed that the "subject be postponed". On June 14, when the subject was again discussed, it was "referred to a committee, with the communications therein mentioned", with instruction "respectfully

${ }^{35}$ Annals of Congress, 13 Cong., 1 sess., 92

${ }^{9}$ Am. State Papers, For. Rel., III, 618; Annals of Congress, 13 Cong., 1 sess., 92.

${ }^{37}$ Annals of Congress, 13 Congress, 1 sess., I, 94.

${ }^{38}$ Annals of Congress, 13 Congress, 1 sess., I, $94 \mathrm{ff}$. 
to confer with the President of the United States upon the subject of said nomination, and report thereon'. The committee consisted of Messirs. Wells, Giles, and King. ${ }^{39}$ After the exchange of notes between the President and the committee in which the President complained of "a continuance of his indisposition", the Secretary of State notified the committee on June 23 , that, in order to obviate any further delay in the proceedings of the Senate on the nomination of the Minister Plenipotentiary from the United States to Sweden, he had been authorized to con. fer with them on that subject and to communicate any information which they might desire from the Executive in relation to it. ${ }^{40}$ On the following day the Senate agreed to the motion by Mr. Goldsborough that it was "inexpedient at this time to send a Minister Plenipotentiary to Sweden". The vote recorded was 22 yeas and 14 nays. ${ }^{41}$ This refusal of the Senate to ratify the appointment of a Minister Plenipotentiary to Sweden was made in full view of the fact that Sweden was virtually the only country in Europe that admitted American merchant vessels without restrictions.

In a communication to the Senate on July 6, the President further explained his failure to meet the Senate committee in a conference. The principal objection was that the President and Senate were co-ordinate departments in regard to appointments and treaties. If the Senate wished information before their final decision the practice was to request the Executive to furnish it. "The appointment of a committee of the Senate to confer immediately with the Executive himself, appears to lose sight of the co-ordinate relation between the Executive and the Senate, which the Constitution has established, and which ought therefore to be maintained". ${ }^{42}$

${ }^{99}$ Annals of Congress, 13 Congress, 1 sess., I, 95.

${ }^{40}$ Annals of Congress, 13 Congress, 1 sess., I, 97.

${ }^{41}$ Annals of Congress, 13 Congress, 1 sess., I, 97-8.

${ }^{42}$ Annals of Congress, 13 Congress, 1 sess., I, 95. 
The principal reason for withholding the ratification of the appointment of Mr. Russell as Minister to Sweden seems to have been connected with his conduct while chargé d'affairs to Paris. In order to trace the problem to its source it is necessary to know that the House of Representatives called upon the President on June 21, to furnish information regarding this matter. On July 12,1813 , the answer came in the form of a long and able survey of the whole relation with France and Great Britain. The French Government had evidently failed to make known to Mr. Russell the supposed repeal of the Berlin and Milan decrees by a decree dated April 28, 1811. The first knowledge of that decree which the Government of the United States had was gained through Mr. Barlow in a communication dated May 12, 1812. The decree was entirely unknown to Mr. Russell, which fact he communicated to Mr. Barlow in a letter of May 11, 1812. ${ }^{43}$

The advisability of appointing a Minister to Sweden at this time has been stated by a well known historian who said: "When 22 senators including Jeremiah Mason, Christopher Gore, Samuel Dana, Rufus King, and William B. Giles, declared that a minister resident in Sweden was inexpedient in the summer of 1813, they declared what every other well informed man knew to be an error. If any American envoy was ever expedient, it was an envoy to Sweden in 1813 ; for in Sweden at that moment all that was left of American commerce centered after being driven from England, and the political interests of Sweden were greatly involved with those of the United States. The error was less to be denied, because, only six months afterwards, the Senate admitted itself in the wrong, and approved the appointment of Mr. Russell. ${ }^{44}$

On January 14, 1814, the President nominated John Q. Adams, J. A. Bayard, Henry Clay, and Jonathan Russell as

${ }^{43}$ Annals of Congress, 13 Congress, 1 sess., II, 2074.

"Adams, Henry, History of the United States, VII, 64. 
commissioners to negotiate directly with Great Britain regarding peace, and the Senate confirmed the nomination, January 18, without opposition except the further nomination of Jonathan Russell as Minister to Sweden, which was "confirmed by the narrow vote of sixteen to fourteen". ${ }^{45}$

The first duty that Mr. Russell was to perform in Sweden was to make known to the Swedish Government the arrangemeut which had been made with Great Britain "to treat at Gothenburg for peace with that power". ${ }^{46}$ But soon Messrs. Bayard and Gallatin agreed with the representatives of the British Government to transfer the negotiations to Ghent. ${ }^{47}$

The second duty that Mr. Russell was called upon to perform was of an entirely different nature. Reference has already been made to the fact that Sweden was forced to adopt the Continental System. This system required the capture of all neutral vessels that entered Swedish waters, and in certain cases Napoleon's own agents sequestered them. Sweden tried in every possibly way to keep on good terms with England and still be neutral. Since all the harbors on the continent and practically the harbors of Great Britain were closed to neutral countries, Swedish ports were swarming with vessels which tried to trade with the belligerents through Sweden. This brought a considerable number of American vessels into Sweden and the Swedish Province of Pomerania in Northern Germany. The sequestration of cotton at Stralsund in 1810 has already been described. In 1814, an agent, Mr. Curwen, was sent to Sweden to investigate some other questions and also to seek "payment for the cotton sequestered at Stralsund". Mr. Curwen was presented to Count Engestrom, the Minister for Foreign Affairs, by Mr. Speyer, the American consul. After a long conversation, the Minister con-

${ }^{45}$ Adams, Henry, Op. Cit., VII, 371.

4i Russell to Count Engestrom, April 30, 1814.

${ }^{17}$ Russell to Monroe, June 6, 1814. 
cluded by saying that if Mr. Curwen would make a communication to Mr. Speyer to be sent to the foreign office, Count Engestrom would give him a letter to Baron Wetterstedt, the chancellor, who was on the continent with the Crown Prince. The final settlement, said the Minister of Foreign Affairs, rested with the Crown Prince. Mr. Curwen went to Karlskrona from Stockholm, and when he reached that place he decided to continue to Gothenburg rather than to go to Stralsund because the Crown Prince, who was one of the leaders in the war against Napoleon, would be too much taken up with battles to pay any attention to elaims against his Government. ${ }^{48}$

Such was the condition of affairs when Mr. Russell was called upon to leave Sweden on the joint mission at Ghent. John L. Lawrence was appointed chargé d'affairs during his absence, which was from June 7,1814 , to May $19,1815 .{ }^{49}$ The servicu of Mr. Lawrence in Sweden was of no great importance, but it was during his stay at Stockholm that the American Government requested the removal of the Swedish consul at Baltimore, Mr. Aquitow, who had been found to be communicating information to the enemy of the United States. In his reply Count Engestrom stated that "his Majesty recognized the principle that a public functionary accredited near a foreign Government, ought to pay due respect to its laws; and should hold no communication, however innocent, with its foes, without its previous knowl. edge and consent". Therefore, if the Government of the United States wished the man removed, it should be done. ${ }^{50}$

The real work for the American Minister came when he was authorized to take up the work left unfinished by Mr. Curwen, namely to obtain indemnity for American property sequestered at Stralsund. In keeping with his instruction Mr. Russell pre-

${ }^{48}$ MeMaster, Life and Times of Stephen Girard, II, $270 \mathrm{ff}$.

${ }^{49}$ House Documents, 19 Congress, 2 sess., No. 73.

${ }^{\text {so }}$ Lawrence to Monroe, February 24, 1815. 
sented the whole question to Count Engestrom, Minister of State for Foreign Affairs.

The facts in the case, briefly stated, were:

1. The sequestration was made at the instance of the French authorities present in Stralsund in June, 1810;

2. In the beginning of August, 1811, the sequestration was raised by the permission of the French authorities, but those authorities still insisted that the money obtained from the sale of the property should be applied to the fortification of Pomerania against the English naval forces;

3. The property was sold by the Swedish authorities;

4. Frequent promises of an indemnity had "ever been made by the Swedish Government to the injured citi. zens of the United States"; ${ }^{51}$

5. The cost of American property in the United States was given as 110,000 Spanish dollars, and the value was estimated by Sweden at 193,000 "rix dollar Pomeranian currency", and sold at 151,000 rix dollar of the same currency.

During the original sequestration the Swedish Government sent more than thirty despatches to France "in order to obtain a release of the sequestered property" or a permission to sell it either on Swedish account or on the joint account of Sweden and France, according to a note sent by Baron Wetterstedt to Mr. Speyer. The Swedish Government never urged any right or justification for the sequestration except the pressure from France, and Sweden always expressed the desire to return the property to the American owners. The American Minister further supported his very able note by a reference to the advantages Sweden had had from Pomerania after the Napoleonic wars; it

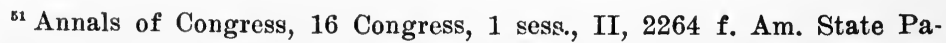
ners, For. Rel., IV, 636. 
had, he said, "furnished an equivalent at the treaty of Kiel for the acquisition of Norway, but subsequently a sufficient consideration for three million and a half of dollars received from Prussia".

In regard to the equivalent for Norway, the fact was that at the treaty of Kiel Denmark ceded Norway to Sweden for Swedish Pomerania. Sweden asserted, however, that since Nor. way was not turned over to Sweden without further fighting, Denmark had violated its claim to the Swedish province. Pomerania was therefore sold to Prussia in connection with the Congress of Vienna. ${ }^{52}$ According to a report from Mr. Russell, the proceeds of the sale of the sequestered property in Pomerania were appropriated: 1) "to pay the inheritance which has fallen due to the former Royal Family about 300,000 Riks-dollar"; 2) "for the property in Sweden belonging to the said family 681,419 Riksdollar 18 shillings and 3 rundstycks"; 3) "the residue to discharge the debts contracted by the last. war". ${ }^{53}$

Practically nothing was heard from these claims for a long time mainly for two reasons : 1) Mr. Russell left Sweden temporarily November 1, 1816, and did not return until December 14 of the following year leaving Mr. Christopher Hughes as charge d' affairs in Sweden during his absence. ${ }^{54}$ Mr. Hughes did not feel inclined to take up the matter since he was filling the position only temporarily; and 2) the parties in the United States sent John Ecky of Philadelphia to represent them. ${ }^{55}$

The Swedish Government admitted to Mr. Ecky, as had been done to all other representatives, the justice of the claims, and the Crown Prince offered him "a quantity of cannon and

\footnotetext{
${ }^{62}$ Russell to Monroe, November 15, 1815.

${ }^{68}$ Ibid.

${ }^{64}$ House Documents, 19 Congress, 2 sess., No. 73.

${ }^{65}$ Hughes to Secretary of State, May 6, 1817.
} 
of gun powder, as a part payment in a reduction of the debt"'. ${ }^{\text {so }}$ This proposition had evidently been made to Mr. Speyer before, for it is spoken of as an old one. But Mr. Ecky received "instructions from his principals not to receive the objects which were offered", ${ }^{57}$ and he left Sweden and went to Hamburg on January 23, 1818. ${ }^{58}$ On his return to United States Mr. Ecky reported the matter to the Secretary of State. ${ }^{59}$

Because Mr. Hughes did not enter into the sequestration claims as vigorously as Jonathan Russell, it must not be assumed that he let the whole matter drop. He had frequent conferences with Count Engestrom, and was referred by him to Baron Wetterstedt who was more intimately familiar with the business being in charge of provincial affairs at the time the sequestration occurred. Baron Wetterstedt acknowledged that the United States citizens had been wronged and declared "the disposition of this Government, and especially of the Prince Royal, to indemnify us for it". ${ }^{80}$ As proof of this disposition the Baron cited the fact that the Prince Royal had offered "a parcel of cannon, powder, and balls which was his own private property to- the agent of the claiments, as a part payment, and as a commencement of restitution". The only reasons this offer was not accepted were that the objects "would not pay the expenses of carrying them to America, and the amount of which ......would not equal one tenth part of the amount of the claims". ${ }^{61}$

Mr. Hughes, nevertheless, almost gave up all hopes of obtaining anything from the sequestration claims. At one time he said: "If it could be once brought to the sense of this Govern-

${ }^{50}$ Hughes to Secretary of State, May 6, 1817.

${ }^{\text {n7 }}$ Hughes to Secretary of State, June 4, 1817.

${ }^{58}$ Russell to J. Q. Adams, January 22, 1818.

"59 Memoirs of John Q. Adams, IV, 424.

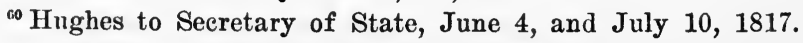

${ }^{11}$ Hughes to Secretary of State, June 4, 1817. 
ment, that it would be for their interest to pay our citizens, they would settle the claims immediately'. But a month later he wrote: "There is an undisguised disposition here to do something for the claiments; but so long as it is believed that our government will be satisfied with this apparent willingness to render justice so long I believe will nothing further be done than to profess that disposition.....". ${ }^{62}$

About this time the old King, Charles XIII, died, and a great deal of extra business had to be taken care of. This was also urged as one reason why the claims had not been attended to more regularly. But on March 19, 1818, Count Engestrom informed the American minister that the affair had been submitted to the King with a request for an order to pay the claims. ${ }^{63}$ In view of this fact the American minister waited for an answer, but none seemed to come. Then Mr. Russell made one more determined attempt. On October 5, 1818, he sent a note to Count Engestrom, in which he briefly reviewed the affair. He said that the representation which had been made to the Swedish Government had not only remained without effect, but had "not even been noticed with the common courtesy of an answer". True, there had been an "interference of a private agent of the American claimant" and his presence "furnished good cause for suspending all communication between the two Governments on the subject", but when that interference "had terminated without effect..... the fitness of such communication between the two Governments was necessarily restored". Mr. Russell added that "to the value of the merchandise should ba added the amount of duties which were paid by the proprietors, and the accumulated interest of more than seven years, in order to constitute an adequate indemnity'". ${ }^{64}$

${ }^{62}$ Hughes to Secretary of State, July 26, and September 1, 1817.

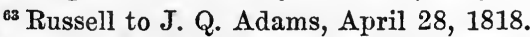

${ }^{64}$ Russell to Engestrom, October 5, 1818; Annals of Congress, 16 Cong: 1 sess., II, 2271; Am. State Papers, For. Rel., IV, 638. 
The effect of this note was that Mr. Russell was asked to meet Count Engestrom at the Foreign Office on October 14, when he received the information that the Minister had not yet received the authorization to communicate any decision, but he gave Mr Russell an invitation from the King to dine with him on the following day. Count Engestrom furthermore asked him to withdraw the above note and send him a new one in which Mr. Russell would remind the Minister of earlier comunications on the subject. Mr. Russell refused to withdraw the note, but he promised to send a note in addition to the earlier one in which the ideas of the Minister should be followed. The reason for this new note was that the note of October 5 , had partly succeeded and partly failed. The belief that the note had succeeded the minister based on the effect it had had in bringing about an invitation from the King and the discussion that followed. The opinion that the note had failed was based on the failure to obtain an indemnity without further discussion and the fear that, if he endeavored to press it, the Government would be supplied with "a pretext for an abrupt termination of all discussion and perhaps for a categorical rejection of the claims". ${ }^{65}$

In answer to the request of the Minister, Mr. Russell sent him a note on October 14,1818 , in which a simple statement. was made of his duty to call "the attention of the Swedish Government once more to the claims of American citizens". $\mathrm{He}$ also said that his confidence in the "justice and liberality of His Majesty" prevented him at the time from "acting on his instructions in their full spirit and extent", requesting "his excellency to cause this matter to be taken into immediate con-

${ }^{65}$ Russell to the Secretary of State, October 16, 1818; Annals of Congress, 16 Congress, 1 sess., II, 268 ff. Am. State Papers, For. Rel., IV: $637 \mathrm{f}$. 
sideration, and to obtain thereon an early and equitable decision". ${ }^{66}$

Mr. Russell left Sweden October 22, 1818, and therefore the answer to his note of October 14, did not arrive before he had gone, but it reached him in Berlin. In this answer Count Engestrom briefly reviewed the whole controversy and expressed a regret that the offer made to Mr. Ecky had been rejected for it "seemed to be the only one adopted to meet the views of Mr. Eckie [Ecky] ". ${ }^{67}$ The Minister also called attention to the fact that, about the same period, "the Swedish Government restored to the citizens of the United States thirty-three vessels, with valuable cargoes, then under detention in Sweden, in consequence of a formal requisition of the mission of France at Stockholm".

The above note was answered from Vienna, on December 12, 1818 , and the answer brought out little that was new, but presented again in a very forceful way the whole sequestration proceedings. Mr. Russell told the Minister that the note from Baron Alquier did not contain the necessary condition that the proceeds from the sale of the sequestered merchandise must be applied to the naval defense of Pomerania, but that the note of July 12, which, in his opinion, was the only one applicable, did not contain any such provision. ${ }^{68}$ The note of December 12 was further supported by a memorial from merchants at Stralsund, who petitioned the Government of Sweden not to sell the property as already advertised. ${ }^{69}$

Both these notes were forwarded, together with the memorial from the merchants, to the United States from Florence or:

${ }^{66}$ Russell to Engestrom, October 14, 1818; Am. State Papers, For. Rel., IV, 637, Annals of Congress, 16 Congress, 1 sєss., II, 2273.

${ }^{67}$ Engestrom to Russell, October 27, 1818; Annals of Congress, 16 Con:gress, 1 sess., IV, 2275.

${ }^{68}$ Russell to Engestrom, December 12, 1818; Annals of Congress, 16 Congress, 1 sess., II, 2275-84; Am. State Papers, For. Rel., IV, 640 ff.

${ }^{\circ 1}$ Annals of Congress, 16 Jongress, 1 sess., II, 2284. 
February 22, 1819. In this report Mr. Russell justified his own action in regard to the note from Count Engestrom. "To have left it without a comment", he said, "would, I believe, have given it a weight to which it was not entitled, and might have been construed into an admission, on my part, that the facts and arguments which it contained were incontrovertible and unanswerable. ${ }^{70}$ To prevent such a construction" he sent an answer complete and strong.

Mr. Russell having been recalled, this was his last communication in regard to the above claims. Mr. Hughes became his successor on October 22, 1818. ${ }^{71}$ In his first despatch to the Secretary of State, Mr. Hughes stated that the notes of Mr. Russell left nothing further for him to do in the line of "discussion with the Government of Sweden on this affair; and what he has said to you without doubt leaves me in the same situation, with respect to my notice of it in this aespatch". ${ }^{72}$ On Decem. ber 1, he also forwarded a copy of Count Engestrom's last note to Mr. Russell for the information of his Government. ${ }^{73}$

So far the claims against Sweden seem to have received little attention of Congress, but on February 7, 1820, "Mr. Burrell presented the petition of Hugh Calhoun and others, pro prietors of certain vesssels and their cargoes unjustly sequestered and sold by the Swedish Government, praying the interposition of the Government of the United States". The petition was referred to the Committee on Foreign Relations "to consider and report thereon". ${ }^{74}$ About a month later, March 11, Mr. Burrell came to the Secretary of State says John Q. Adams "to press what are called the Stralsund Claims upon the Swedish

${ }^{70}$ Russell to J. Q. Adams, February 22, 1819; Annals of Congress, 16 Clongress, 1 sess., II, 2273.

"House Documents, 19 Congress, 2 sess., No. 73.

${ }^{72}$ Hughes to J. Q. Adams, October 23, 1818.

${ }^{73}$ Hughes to Secretary of State, December 1, 1818.

"Senate Journal, 16 Congress, 1 sess., 140 f. 
Government. I gave him a particular account of what had been done, and read to him Mr. Russell's last note to the Swedish Minister of Foreign Affairs, Count Engestrom, concerning these claims, and the subsequent correspondence of C. Hughes relating to them". ${ }^{75}$ On March 25, the Senate passed a resolution requesting the President to submit to it information relating to the Stralsund Claims. In response to this resolution the above correspondence was submitted, ${ }^{76}$ but nothing was accomplished.

For some time very little was done in regard to the Stralsund claims, but on December 14, 1822, Count Engestrom reviewed the whole affair in a note to Mr. Hughes; and he blamed the "Continental System" and its author for the whole incident. ${ }^{77}$ That communication appears to be the last one from Count Engestrom on the subject, for he retired to private life June 10, 1824, and was succeeded by Baron Wetterstedt. ${ }^{78}$

Since nothing could be accomplished through diplomatic channels Mr. John Connell was sent to Sweden as the agent "of Stephen Girard and others". The King being absent from the Capital, Mr. Connell had to wait about three months before he could present his memorial, which he did October 18, 1824. ${ }^{79}$ This representation was made with the knowledge and approbation of the President of the United States. Baron Wetterstedt answered that he did not know how soon he could find the money to repay the damage to the United States. The Swedish Government recognized the justice of the claims and admitted "the fairness of the terms, but the King was incapacitated by the Constitution to act except by and with the consent of the Diet," and that body would not meet, unless called into special session, before 1828. Mr. Connell's papers were returned to him

\footnotetext{
${ }^{75}$ Memoirs of John Q. Adams, V, 17.

${ }^{76}$ On April 21, 1820; Annals of Congress, 16 Congress, 1 sess., II, 2264.

${ }^{77}$ Engestrom to Hughes, December 14, 1822.

${ }^{7 s}$ Wetterstedt to Hughes, June 30, 1824.

${ }^{79}$ Inclosure from Hughes to Secretary of State, November 24, 1824.
} 
and the business was left on the old footing. But on January 31, Mr. Hughes received a note from Baron Wetterstedt requesting him not to press the matter for he was gaining ground in the eabinet. It was expected, he said, "that if the matter was reported favorably, the Diet would act favorably'. ${ }^{80}$

On February 7, 1825, Mr. Hughes notified his Government that Baron Wetterstedt offered to cede and sell the island of St. Bartholomew to the United States and that the indemnities of the citizens of the United States might then be settled from the proceeds of the sale. That proposition had, in fact, been made in 1818-19, but one reason why the United States did not buy the island was that the price 200,000 pounds sterling was considered "wild and extravagant". Baron Wetterstedt admitted that the sum was rather large and intimated that about 500,000 dollars would be asked at this time. He added that the nearness of the island might make it important as a naval station for the United States. ${ }^{81}$

Two months later the envoy reported that he had had a conference with Baron Wetterstedt at which the latter made alternate proposals :

1) that an unofficial engagement in form of a note be addressed to Mr. Hughes, recommending the liquidation at the next Diet, which the Count considered as a virtual, though a dilatory, settlement; or,

2) by an offer of a round sum to Mr. Connell against a full and final discharge. The Count, in fact, preferred the latter plan for settlement.

Mr. Hughes reported that "No attempt is made to deny the justice of the claims; on the contrary, it is admitted in every conference in the broadest and most unqualified terms".

If the first alternative should be decided upon Mr. Hughes

${ }^{20}$ Hughes to Secretary of State, February 3, 1825.

"Hughes to Secretary of State, February 7, 1825. 
felt satisfied by having the assurance that the matter would be recommended to the Diet. On the other hand, if the latter alternative should be agreed upon, Mr. Hughes would leave the settlement entirely to Mr. Connell, who had been supplied with full powers and "on whom will rest the responsibility for the settlement'".

At the same conference Count Wetterstedt said that if the United States would buy St. Bartholomew, he would settle the whole affair at once; for as a colony the King had uncontrolled right to dispose of it. ${ }^{82}$

Count Wetterstedt requested a copy of all the correspondence concerning the Stralsund claims, and Mr. Hughes sent them on Sunday evening, April 24, 1825. In addition he stated that it took the Swedish Government only twenty-one days to sell and apply the property, but it took fifteen years of negotiations for an indemnification. ${ }^{83}$ Now Mr. Connell might make any compromise he pleased.

About two weeks later the envoy again wrote to Count Wetterstedt regarding a conference they had had with regard to the claims. Mr. Hughes was to confer with Mr. Connell and report the result, which he did in the following manner: "I have seen Connell, and his answer to the questions your excellency mentioned to me an hour ago [in conference] follow.

1. "No insurance company is interested in the claims;

2. "The property belongs to citizens of the United States and no other description of persons";

3. The claimants are the original proprietors of the property; the identical persons from whom the property was taken in 1810 ;

4. "The sufferers have never received the smallest indemnity from the Insurance companies; the property was

${ }^{82}$ Hughes to Secretary of State, April 7, 1825.

${ }^{88}$ Hughes to Secretary of State, April 24, 1825. 
safe in port, and had paid duties; it was in warehouses and therefore the duties of the insurance companies ceased".

Mr. Connell also stated that "his principals have engaged to ratify all his acts",. ${ }^{84}$

In a letter to Henry Clay, Mr. Hughes wrote, June 21, 1825, "It cannot go many days more until a final settlement of the Stralsund claims are made, for the offer of a round sum in cash has been made to Mr. Connell, but Connell is trying to get 10,000 dollars more than the sum offered. It will be decided one way or the other in a few days"'. 85 On July 16, the agreement was reached and the necessary documents signed. The following is the wording of the original document: "Whereas, during the year One thousand eight hundred and ten, sundry goods, wares and merchandize belonging to citizens of the United States of America, were put under sequestration at Stral. sund in Pomerania, then a dependency of the Crown of Sweden; and whereas, said property was disposed of at Stralsund during the year one thousand eight hundred and eleven, and the proceeds thereof paid into the Royal Treasury of Pomerania; and whereas the subscriber is legally authorized by the full power of attorney, to settle, compromise and adjust said claims, in such manner as he may judge expedient and fit and also to receive payment to give a full and satisfactory discharge for the same therefore by virtue of the aforesaid authority, and in consideration of the fund of Sixty thousand dollars Hamburg Bancs paid in hand, in a Bill of Exchange at 90 days date, upon Hamburg, drawn by C. D. Shogman Esq. His Swedish and Norwegian Majesty's Secretary of State and for the Department. of Finance and Commerce, do hereby declare, that I accept of the said Sixty thousand Dollars Hamburg Bancs, as a full and

\footnotetext{
"Hughes to Wetterstedt, May 9, 1825.

${ }^{\mathrm{R}}$ Hughes to Clay, June 21, 1825.
} 
complete indemnity to the claimants aforesaid and I forever release the Government of Sweden from any further claims, for or on the acount of any losses or damages which may have accrued in consequence of the sequestration and sale of the said American property at Stralsund '. ${ }^{86}$

The Swedish Government also required a release from the American envoy, which was given with the assurance that he would "communicate the above pleasant intelligence..... to his government, and he is convinced that it will be a source of sincere satisfaction to the President, to learn that the long pending and single difficulty, in the diplomatic relations of the two Governments is settled and forever put to rest"'. ${ }^{87}$

These documents were later forwarded by Mr. Hughes to the Secretary of State, August 8, 1825. The part played by the envoy in the negotiations was limited to giving the formai discharge after the other parties had agreed on a settlement. But since the Swedish Government asked for it, the business could not be concluded without his participation. ${ }^{88}$ The President could, therefore, announce to Congress that the claims on "Sweden have been lately compromised by a private settlement, in which the claimants themselves have acquiesced". ${ }^{89}$

"State Department Archives.

${ }^{87}$ Stockholm, July 16, 1825.

${ }^{88}$ Russell to Secretary of State, August 8, 1825.

${ }^{89}$ Message to Congress, December 6, 1825; Am. State Papers, For. Rel., V, 760; Senate Documents, 19 Congress, 1 sess., I, Doc. 2, p. 5 ; Messages and Papers of the Presidents, II, 867. 
CHAPTER IV

\section{Commercial Relations}

"The two contracting parties grant mutually the liberty of having each in the ports of the other, consuls, vice consuls, agents, and commissaries, whose functions shall be regulated by a particular agreement"'. 1 Such is the basis for commercial relations laid down in the treaty of 1783 . In keeping with these prc visions, Swedish consuls were early admitted to Philadelphia and Boston. A'ready on December 3, 1784, a committee of Congress, composed of Messrs. Monroe, Houston, and Howell, to whom had been referred a "commission of consul from his majesty the King of Sweden, to Charles Hellstedt," dated September 22, 1783, reported in favor of receiving him as consul to reside in Philadelphia in the following resolution: "Resolved, That the said commision be registered in the Secretary's office; and that thereupon acts of recognition in due form be immediately issued to the several states, in order that they may respectively furnish him with an exequatur or notification of his quality, that the same may be known and published"." In May of the following year a similar resolution was adopted to register the commission of Richard Soderstrom "as consul of the Swedish nation at Boston" Massachusetts, "and that thereupon an act of recognition in due form be immediately issued to the commonwealth of Massachuetts, in order that they may furnish the said Richard Soderstrom with their exequatur or notification of his quality, that the same may be made known and

\footnotetext{
${ }^{1}$ Journal of the American Congress (1774-88), IV, 246.

${ }^{2}$ Journal of the American Congress (1774-88), IV, 449.
} 
published". ${ }^{3}$ On May 3, 1797, Richard Soderstrom was made Consul General for the United States, with Joseph Winthrop as vice-consul for South Carolina and Georgia. The Vice Consul arrived on May 26, 1797.

Sending consuls to reside at the ports of another country is but one way of commercial assistance, there being other ways which may become just as effective. In 1786, while Thomas Jefferson was in France, he was approached by Baron Stael von Holstein, the Swedish Ambassador at Paris, on the question as to how the Swed: in Island of St. Bartholomew could be made most useful to the commerce of the United States. In his answer to this inquiry, Mr. Jefferson gave an analysis of the whole subject. He said that the island in itself would furnisin little of its own production that would be of interest. "It remains then to make it the instrument for obtaining through its intermediation such American productions as Sweden can consume or dispose of, and for finding in return a vent for the native productions of Sweden". If the island therefore would be made a free port without a single restriction the following consequences would follow:

1. It would draw to itself that tide of commerce "which at present sets towards the Dutch and Danish" islands, because vessels going to those islands were often obliged to negotiate a part of their cargoes at St. Eustaticus, and to go to St. Thomas to negotiate the residue, whereas when they would know that there was a port where all articles are free both for importation and exportation, they would go to that port which enabled them to perform by one voyage the exchanges which hitherto they could only effect by two;

2. Every species of American produce whether precious

${ }^{3}$ Journals of Congress, X, 130; Secret Journal of the Congress of Cinfederation, Foreign Affairs, III, 555. 
metals or commodities, which Sweden may want for its own consumption or "as aliment for its own commerce with other nations, will be collected either fairly or by contraband into the magazines of Saint Bartholo. mew"';

3. All the production which Sweden can furnish within itself or obtain to advantage from other nations, will in like manner be deposited in the magazines of St. Bartholomew, and will be carried to the several ports of America in payment for what shall be taken from them.

Mr. Jefferson also saw that this plan might meet with objections and he therefore met the objections from the start. "If it be objected", he said, "that this unrestrained license will give opportunity to the subjects of other nations on exchanges there in which Sweden will be in no ways interested; I say, 1. That there will be a few of these operations into which the Swedish merchants will not be taken in the beginning or in the long run; 2 . There will be a few of these exchanges into which Swedish productions will not enter, when productions of that nature are wanted in return; 3. But suppose neither Swedish merchants nor productions enter into the operations, what objections can Sweden have to other peoples' meeting in one of her ports to carry on commercial exchanges"?"

Baron Stael must have been under instructions from his home Government and given the plan his hearty approval, for when the King of Sweden in $\mathbf{1 7 8 6}$ reported to the Riksdag what had taken place since their former meeting he said that "a treaty of commerce......had been concluded with the United States"; the island of St. Bartholomew had been acquired and "now declared a free port" which had given Sweden a footing in the West Indies. ${ }^{5}$

4 Writings of Thomas Jefferson (Ford, ed.), IV, $238 \mathrm{f}$.

- Quoted by Bain, Gustavus III and his Contemporaries, I, 286. 
The opening of St. Bartholomew as a free port was made in the interest of the mutual trade while Spain and Portugal refused "to all those parts of America which they govern, all direct intercourse with any people but themselves". ${ }^{\circ}$

During the early days of independence, the commerce of the United States suffered greatly from the activity of the Barbary pirates. In order to obtain some light as to the action of other nations in this regard, John Adams inquired from Baron Stael von Holstein, "concerning the presents given by their courts to the Barbary powers"'. The Swedish Ambassador promised to write to Stockholm" for full information upon this subject".? Whether any information was obtained from this inquiry or the information was not acted upon, the usual sources do not state. But in a short time there came an opportunity for Sweden to assist the United States in Algiers in another way. Captain O'Brian wrote to the President of the United States, on November 5, 1793, that the Swedish consul in Algiers, Mathias Skjoldebrand, had befriended ten American vessels with 105 inen and given them "money to relieve their greatest necessities". The Captain expressed the hope that "you will order him to be reimbursed, and also paid for his generous advance in the ransoming of George Smith, one of the subjects of the. United States". 8 The following week, November 1793, Captain O'Brian wrote at length to Mr. D. Humphreys about the same question in these words: "The Swedish consul depend, would do all possible in his power to serve the Americans; but, Sir, you will consider that for him to interfere publicly in the American business, that he should first have the order of his court; but you may depend on his interest in all that can be done with propriety".

The brother of the Swedish consul was also present in Al-

- Writings of Thomas Jefferson (Ford, ed.), VI, 476, 477.

"Works of John Adams (C. F. Adams, ed.), VIII, 227.

'Am. State Papers, For. Rel., I, 418. 
giers. On request, he took a letter from the President to the Dey, " and made use of every winning and requisite argument, for the Dey to consider favorably of a peace with the United States, and permit the American Ambassador to come to Algiers; but the Dey has not seemed inclinable, but gave Mr. Skjoldebrand Jr. nearly the same answer as he gave Bassara". Captain O'Brian thought the Dey was "prepossessed against the Americans by the British consul, who had information of your [Mr. Humphrey's] destination by the captain of the Portuguese frigate, and by Mr. Walpole, British resident at Lisbon'. Since the Minister, Mr. Humphreys, was fully empowered and there was great necessity of "something decisive being done", Captain O'Brian suggested that Mr. Skjoldebrand Jr. ought to be empowered by the minister "to adopt such plans as will be most effectual, and be most conducive in bringing about peace"."

The following day the Swedish consul general of Algiers wrote to Mr. Humphreys and explained his position in regard to any negotiations between the United States and Algiers. He said that his steps would be very carefully guarded in every particular and if he should do anything in favor of the Americans, that would instantly be reported to every "court of Europe, who would complain to the court of Sweden'. In view of this fact he might be censured "for having acted..... without order or permission" of his court. For that reason he determined to use his brother who was in Algiers in an unofficial capacity to deliver the letter of eredence for the American Minister and the: memorial to the Dey. The Swedish consul also suggested to $\mathrm{Mr}$. Humphreys that if he wished to use his brother for communicating with the Dey, that procedure was easily available and he would be glad to serve. ${ }^{10}$ The same day Pierre Eric Skjoldebrand also wrote to Mr. Humphreys and told him that the Swed.

\footnotetext{
- Am. State Papers, For. Rel., I, 416.
}

${ }^{10}$ Am. State Papers, For. Rel., I, 414. 
ish consul had been refused admission to Algiers just as the American minister had, but that they demanded permission to come and he advised Mr. Humphreys to do the same. ${ }^{11} \mathrm{He}$ promised to aid the United States in every way possible if Mr. Humphreys should desire to use him; but if "you be pleased to honor me with your confidence, I request you, sir, to be so good as to remember to give me also a power to make use of it." 12

Mr. Humphreys reported all these things to the Secretary of State on November 23, 1793, adding that by the tenor of these letters "you will clearly comprehend the actual disposition of the Dey, and the real state of affairs in the regency". ${ }^{13}$ In his report a month later, December 25, 1793, he said that there were reasons "to apprehend that some of the combined Powers may have an agency in this business". Mr. Humphreys also lamented the departure of Mr. Pierre Eric Skjoldebrand as an "extremely disagreeable and inconvenient circumstance for us". 14

The departure of Mr. Skjoldebrand must, however, have been only temporary, for he was appointed United States consul to Algiers after the death of John Paul Jones, on March 28, 1795. ${ }^{15}$ Again, when Joseph Donaldson Jr. was appointed consul for the two States Tunis and Tripoli, it was suggested that he should "be employed in an agency with Pierre Eric Skjoldebrand [now named as consul of the United States to Algiers] in ascertaining and agreeing upon the provisional or preliminary terms of a treaty with Algiers". ${ }^{16}$

Nothing further has been recorded about the work of Swe-

${ }^{11}$ Am. State Papers, For. Rel., I, 415.

${ }^{12}$ Am. State Papers, For. Rel., I, 415.

${ }^{13}$ Am. State Papers, For. Rel., I, 413.

${ }^{14}$ Am. State Papers, For. Rel., I, 418.

${ }^{15}$ Annals of Congress, 13 Cong., II, 2669 ; Paullin, C. O. Diplomatic Ne gotiations of American Naval Officers, 42.

${ }^{16}$ Am. State Papers, For. Rel., I, 529. 
dish consuls in Algiers in the behalf of the United States until the peace commissioners were sent to Algiers. Then Monroe suggested in the instructions dated April 10, 1815, that the Peace Commissioners, "before proceeding to extremities" should make use of the Swedish consul, Mr. Norderling, who "has beeri friendly to the United States". Mr. Norderling could be authorized to carry a letter from the President of the United States to the Dey of Algiers and "be authorized and instructed to give such answers to the inquiries of the Dey and to make such communications to him as you may deem most likely to accomplish the objects in view'. ${ }^{17}$

The first consul from the United States to Sweden was Elias Backman, whose appointment was dated on February 27, 1797. On April 27, 1810, Robert G. Gardiner was reported as consul at Gothenburg, Sweden. ${ }^{18}$

The activity of some of these consuls was not always in the interest of friendship between the two nations. Thus the American Charge 'd affairs, Christopher Hughes, received a letter of complaint from Count Axel Rosen, the governor of the district in which Gothenburg is located. The governor requested "an immediate examination" of the case of the man, Joseph Hall, who "no longer merits the honorable confidence to be consul of the United. States'. ${ }^{19}$ About a week later, Mr. Hughes reported to the Secretary of State that Joseph Hall "is now in prison for custom house dues to a great amount"'. The chargé d' affairs asked instructions from his Government in regard to what course to pursue. ${ }^{20}$ On June 5th, Mr. Hughes reported that the former consul had "escaped from his prison and absconded", and no further information has been obtained regarding

\footnotetext{
${ }^{17}$ Writings of James Monroe (S. M. Hamilton, ed.), V, 373.

${ }^{18}$ Annals of Congress, II Cong., 2 sess., 1998.

${ }^{10}$ Rosen to Hughes, May 18, 1817.

${ }^{20}$ Hughes to Secretary of State, May 28, 1817.
} 
his ease. ${ }^{21}$ In the same despatch Mr. Hughes notified his Gov. ernment that he had "authorized Mr. C. A. Murry of Gothenburg" to assume his duties of consul "until the pleasure of the President shall be known on the subject,". ${ }^{22}$

A year later, when Mr. Russell had returned to his duty, he wrote to John Q. Adams that "the interest of our commerce and particularly the protection of our seamen require" the appointment of some one to perform the duties of consul in Stockholm. It had been suggested that the secretary of the legation or the chargé d' affairs should be authorized to perform the duties of consul. Mr. Russell very strongly advised against that course, ${ }^{23}$ but the Government had already on May 28, 1818, appointed David Erskine.

The commercial treaty of 1783 with Sweden came to an end in 1798. Although John.Q. Adams was authorized to renew the treaty and was removed from Spain to Prussia partly for that purpose, the treaty was allowed to come to an end without a new one being undertaken. It was not before Mr. Russell had become Minister to Sweden that a new treaty was finally concluded, September 4, 1816. The treaty was submitted to the Senate for consideration on Decmber 13, 1816. ${ }^{24}$ The Senate discussed the treaty and advised its ratification except articles III, IV and VI. Those articles referred to the carrying trade between the two countries. Article three provided that all articles produced or manufactured in the West Indies, which could be imported into Sweden and Norway in their own vessels, might likewise be imported into those countries in the vessels of the United States with no extra duties except only ten per cent of the regular

${ }^{21}$ Hughes to Secretary of State, June 5, 1817.

${ }^{22}$ Hughes to Secretary of State, June 5, 1817.

${ }^{23}$ Russell to John Q. Adams, Jan. 20, 1818.

${ }^{24}$ Annals of Congress, 14 Cong., P. 1973; Messages and Papers, I, 566; ratification was advised with amendments, February 19, 1817; Am. State Papers, For. Rel., IV, 98 ff; Malloy, Treaties and Conventions, II, 1742. 
duties on vessels and cargoes. Article four contained the same provision in regard to articles produced or manufactured in "the countries surrounding the Baltic Sea', imported into the United States. Article six specified that whatever the chief custorn officer should designate and specify as products of a country in the clearance papers delivered to the vessel on its departure from port that should be acknowledged and admitted as such in the country of destination. ${ }^{25}$

The discussion of the amendments consumed a considerable amount of time, so that the Swedish Government became uneasy as to the fate of the treaty. The chargé $d$ ' affairs wrote to the Secretary of State in September 1817, that "It may be proper to mention the very great fear entertained and expressed here that Mr. Russell's treaty should be put into practical operation". Mr. Hughes explained that he had received no instruction "on the supposition that no subject of that nature would be taken up at Washington, until the return of Adams from London". There was also an uncertainty in regard to Mr. Russell's return to Stockholm. ${ }^{2 n}$ But when Mr. Russell returned he had received instructions that the Senate had rejected the third, fourth and sixth articles of the treaty of commerce. He had several subsequent conferences with Count Engestrom in order to ascertain the views of the Swedish Government relative to the treaty, and he expressed his belief that the treaty would eventually "be accepted with the retrenchment made by the Senate"'. ${ }^{27}$

On January 24, 1818, Count Engestrom notified Mr. Russell "that he was authorized to state that Sweden" would not insist on these articles, since they "were not of particular interest to Sweden". He was therefore ready to exchange the ratifications as soon as "Mr. Russell should receive the treaty properly

${ }^{28}$ See Am. State Papers, For. Rel., IV, 98 ff.

${ }^{28}$ Hughes to Secretary of State, September 1, 1817.

${ }^{27}$ Russell to Secretary of State, December 29, 1817. 
signed'. ${ }^{28}$ The ratifications were exchanged on September 25, 1818.

For some reason the Swedish Government delayed to put the provisions of the treaty into operation and therefore Mr. Hughes who, on the departure of Mr. Russell, was made chargé d' affairs in October 1818, sent a note to Count Engestrom requesting "that the requisite orders" be issued by the Swedish Government putting the treaty into operation and that the proper authorities should be required to "refund to the American citizens, or to their agents, the duties which have been erroneously paid by them, subsequent to the exchange of the respective ratifications" of the treaty. ${ }^{29}$ The effects of this note could not have appeared when the American Consul in Gothenburg wrote to Mr. Hughes about the same question ${ }^{30}$ on November 7, and on the tenth Mr. Hughes received a note from Count Engestrom in which he informed the chargé d' affairs that the obligations in regard to the treaty were being discharged and that "measures were taken to reimburse American citizens who had suffered on this account". ${ }^{31}$ The minister of foreign affairs explained to Mr. Russell that the reason for the delay in putting the treaty into operation was that this duty "came under the department of State and Commerce and therefore outside of his field, but that he issued a request to that department to hurry matters and he believed it was now in force". ${ }^{32}$

On January 25, 1819, John Norderling, former Swedish Consul General at Algiers, called on Mr. Hughes to inform him that he had been officially notified by Count Engestrom of his appointment as chargé d' affairs in Washington. Mr. Hughes add-

${ }^{28}$ Count Engestrom to Russell, January 24, 1818.

${ }^{29}$ Hughes to Count Engestrom, November 3, 1818.

${ }^{30}$ C. A. Murry to Hughes, November 7, 1818; House Documents, 19 Cong., 2 sess., No. 73.

${ }^{31}$ Engestrom to Russell, November 10, 1818.

${ }^{32}$ Hughes to Secretary of State, December 4, 1818. 
ed to the above notice to his Government that Mr. Norderling "has already a knowledge of our constitution and form of Government which is rarely met with in Europe......". ${ }^{33}$ In February Mr. Hughes, at the request of Count Engestrom, informed his Government that Mr. Norderling had been appointed as chargé d' affairs at Washington. A few days after the date of this despatch "the news was received of the death of the Gov. ernor of St. Bartholomew". Mr. Norderling was then appointed to fill the office of Governor for St. Bartholomew, and in his place Baron Stackelberg was appointed to Washington. ${ }^{34}$

Count Engestrom informed Mr. Hughes that Mr. Norderling reluctantly yielded to this change for though the remuneration of Governor was “double those of the chargé d' affairs, Mr. Norderling preferred very much the latter place'”. The Count also expressed his belief and hope that the functions and residence at St. Bartholomew would only be temporary and that on their expiration he would change posts with Baron Stackelberg. ${ }^{35}$ The appointment of Baron Stackelberg was dated January 1, 1819, "at which period Mr. Kantzow vacated the place", but Baron Stackelberg did not leave Sweden before May 28, 1819. ${ }^{36}$

So far there had been a considerable distinction between the vessels of the country and those belonging to the United States. The Swedish Government must have realized that such a condition of affairs was unfavorable to its commerce, for on January 25, 1821, Count Engestrom sent a note to the American chargé d' affairs in which he informed him that the King had given "express orders" to notify Mr. Hughes that "vessels belonging to citizens of the United States, as well as their cargoes" would be subject, "in the ports of the Kingdom of Norway, to no higher duties of entry or clearance, than those payable by the

${ }^{83}$ Hughes to John Q. Adams, January 26, 1819.

${ }^{34}$ Hughes to Secretary of State, February 25, 1819.

${ }^{35}$ Ibid.

${ }^{*}$ Hughes to Secretary of State, May 27, 1819. 
national vessels and their cargoes". This action removed "every sort of distinction between Norwegian and American vessels". Neither the place from which a vessel came nor the destination of a vessel should be any cause for exception from this general. rule. The nature of the cargo should not be the cause for any exception for the "cargo may consist of the production of the soil, or of the industry of such country, whatever it may be". Mr. Hughes was requested to forward this information to his Government. ${ }^{37}$

The following July the Swedish chargé d' affairs in Washington addressed a note to the Secretary of State "to inquire if, in virtue of the commercial regulations in the United States, the Norwegian commerce" would enjoy in the ports of the United States, "the same advantages and immunities which have been lately. granted in the ports of Norway to the American commerce". 38 In a few days the Secretary of State answered the above note, but in doing so he pointed out that the act of March 3, 1815, which served as a basis for reciprocal action on the part of the United States, was not so extensive as that of Sweden and Norway in that the act of the United States strictly limited its application to "the produce or manufacture of the nation". The above act was subsequently amended by an act, of March 3, 1819, limiting the application of the act to January 1, 1824. The United States could not, therefore, offer as comprehensive freedom to trade as the Swedish and Norwegian Government had done. But, if it was desired, the President of the United States would issue a proclamation granting to the Norwegian vessels all the freedom of commerce which the laws of the United States permitted. ${ }^{39}$ Stackelberg requested, in an answer

${ }^{87}$ Engestrom to Hughes, January 25, 1821; House Documents, 17 Cong., 1 sess., No. 123.

${ }^{38}$ Stackelberg to Secretary of State, July 11, 1821; House Documents, 17 Cong., 1 sess., No. 123.

John Q. Adams to Stackelberg, July 23, 1821, House Documents, 17 Cong., 1 sess., No. 123. 
to the above note, that all the advantages which could be granted to Norwegian vessels under existing laws should be granted. He also suggested that a law ought to be passed in the United States according to which the commerce of the two countries could be established on "perfect reciprocity". ${ }^{40}$ In accordance with the above note, the President issued a proclamation that since "satisfactory proof" had been received "under date of the 30 day of January 1821, that henceforward all discriminating or countervailing duties in the Kingdom of Norway, so far as they operated to the disadvantages of the United States had been and were abolished". ${ }^{41}$ A copy of the proclamation was sent to Baron Stackelberg on the following day. ${ }^{42}$

At the opening of Congress the following December, President Monroe called attention to this commercial arrangement with the King of Sweden and Norway regarding Norway. He called the attention of Congress to the fact that the chargé $d$ ' affairs had "requested the reciprocal allowance for the vessels of Norway in the ports of the United States"' as were allowed vessels of the United States in that country. Since the act of: March 3, 1815, was insufficient for the purpose and Congress was the only part of the Government which could grant the privilege, the President submitted the subject "to the wisdom of Congress". ${ }^{43}$ It seems, however, that Congress must have taken a rather liberal amount of time for considering the subject, for on May 1, the following year, the President sent a special message to Congress suggesting again the advisability of such legisla-

${ }^{40}$ Stackelberg to the Secretary of State, August 16, 1821, 17 Cong., 1 sess., No. 123.

${ }^{11}$ Messages and Papers of the Presidents, 1, 665.

${ }^{12} \mathrm{John}$ Q. Adams to Shackelberg, August 21, 1821, House Documents, 17 Cong., 1 sess., No. 123.

${ }^{43}$ Annual Message on December 3, 1821, Messages and Papers, 1, 671; House Journal, 17 Cong., 1 sess., pp. 15, 544. 
tion. The message was accompanied with all the correspondence on the subject. ${ }^{44}$

The ports of Sweden were not included in the above ar. rangement, but the question of admitting American ships with products from West Indies into Sweden on the same condition as Swedish vessels was submitted to the Diet, and that body decided to leave the whole question "to the discretion of the King'". 45 The King decided in favor of this extension of commercial privileges and therefore instructed Count Engestrom to notify Mr. Hughes to that effect, which was done on April 3, 1824. ${ }^{46}$ The King did not demand reciprocal action on the part of the United States, but Mr. Hughes, in reporting this information to the Department of State, observed that it was "confident. ly hoped and expected that some analogous favor and facility would be accorded on the part of the Government of the United States to Swedish ships and their trade in the United States Ports', ${ }^{47}$ In view of this arrangement Mr. Monroe could announce at the opening of Congress that "our commerce with Sweden has been placed on perfect reciprocity". ${ }^{48}$ In this way, therefore, the provisions of the treaty of 1816 , which were rejected by the Senate, were obtained and secured.

The removal of commercial restrictions in St. Bartholomew no doubt was of considerable importance and seemed to extend the commerce. In October 1820, Richard Rush wrote from that island that "the Swedes and the Danes will, in some measure, become the carriers of provisions, etc., for the supply of the aforesaid colonies; for since my arrival here more than thirty British vessels have assumed the Swedish flag, and, no doubt,

${ }^{44}$ Messages and Papers, 1, 707; House Documents, 17 Cong., 1 sess., No. 123.

${ }^{45}$ Hughes Memorandum to the Department of State.

${ }^{4}$ Engestrom to Hughes, April 3, 1824.

"Hughes to Secretary of State, April 3, 1824.

${ }^{48}$ Eight Annual Message, Messages and Papers, II, 820. 
in St. Thomas to a greater extent". ${ }^{49}$ But the regulations in regard to the admission of consuls to the colony was somewhat restricted. There may have been several reasons for this restriction. The two principal reasons for this limitation were that, "it was a colony, and because during the French Revolution a consul from France had been admitted there", and he "had proved very troublesome by his turbulance". These objections were answered completely and convincingly by John Q. Adams. He observed that neither of these reasons could "justify the refusal to receive an American consul at St. Bartholomew". European Governments excluded consuls from their colonies because foreign commerce with those colonies "was interdicted". If the commerce was interdicted there could be no need of consuls, but if commerce was allowed the consul followed as a matter of "course-as much as an army implied a general". The Swedish Government had allowed foreign commerce with St. Bartholomew, and also specifically named the island in the treaty between the United States and Sweden. ${ }^{50}$ The inhabitants of the island, "their vessels and their merchandise", were entitled to the same advantages in the United States as those of Sweden, " and the citizens of the United States were entitled to the same in the island as Sweden. The province of a consul was to secure in effect to the people of his nation the real enjoyment in foreign ports of the commercial advantages to which they are entitled by treaty, or by the laws of nations". ${ }^{51}$

If these arguments influenced the Swedish Government or not is difficult to state, but the following March Count Engestrom notified Mr. Hughes that the Swedish Government would issue an exequatur to a United States "consul at St. Bartholomew"'. ${ }^{52}$ $\mathrm{V}, 89$.

${ }^{40}$ Rush to John Q. Adams, October 4, 1820; Am. State Papers, For. Rel.,

so Treaty of September 4, 1816; see also Am. State Papers, For. Rel., $\mathrm{V}, 892$.

${ }^{51}$ Memoirs of John Q. Adams, VI, 32.

${ }^{62}$ Engestrom to Hughes, March 18, 1823. 
In the following December, therefore, Mr. Hughes demanded the recognition of the United States consul at St. Bartholomew in accordance with the treaty with the United States. Count Engestrom admitted in unqualified terms the high character of the consul and that "no objection existed to him on personal grounds". 53

The so called "Russell Treaty" expired by its own limitations eight years after ratifications were exchanged. The exchange of ratifications took place on September 25, 1818, wherefore the treaty expired on September 25, 1826. ${ }^{54}$ This treaty was also allowed to expire before a new one was agreed upon. The reason for this fact was that Mr. Somerville, who was appointed to act as envoy, in that capacity became sick and diea. In order to continue the commercial relations provided for in the treaty the Swedish chargé d' affairs in Washington addressed a note to the Secretary of State on September 26, announcing that the Government of Sweden had decided to consider the provisions of the old treaty in force until a new one should be agreed upon. He was also "authorized to propose to the American Government to give similar orders in the ports of the United States in regard to the Swedish and Norwegian Commerce". In addition Baron Stackelberg stated that the King desired that the new treaty should be signed at Stockholm, and he expressed the wish of the King that the President would "send some one as soon as possible to treat in this affair'. The Swedish chargé $d$ ' affairs also stated that Mr. Hughes, the American chargé d' affairs, in Stockholm, would be acceptible to the Swedish Government to act in that capacity. ${ }^{55} \mathrm{Mr}$. Hughes, however, was not appointed, but Mr. John J. Appleton, chargé d' affairs in Spain.

At the opening of Congress the President submitted the question as to the continuation of the provisions of the treaty

${ }^{83}$ Hughes to John Q. Adams, December 7, 1823.

${ }^{5}$ Am. State Papers, For. Rel., VI, 367.

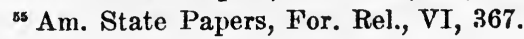


with Sweden to Congress for its consideration. ${ }^{56}$ The chairman on the committee on Commerce, Mr. Tomlinson, introduced a bill containing the above provisions. An opinion was expressed that the act of 1824 regarding the commerce with Sweden covered the case, but members of the committee held the opposite view. ${ }^{57}$ In the meantime, Swedish vessels had arrived in the United States, and had been required to pay the "foreign duties". ${ }^{5 s}$ The new act authorized the return of such duties charged during the interim. Baron Stackelberg was informed, March 16, 182' $\overline{\text {, }}$, that Congress passed a bill to "except Swedish and Norwegian vessels from the payment of descriminating duties of import and tonnage for a limited time". ${ }^{59}$

The instructions to Mr. Appleton were dated on January 12, 1827. According to those instructions the chargé d' affairs was authorized to renew the treaty with the exception of those articles which the Senate rejected in advising its ratification. $\mathrm{He}$ was further instructed that the United States desired to see the provisions in the treaty that vessels of both parties should be "entitled to navigate between the ports of Sweden and Norway and the Swedish colony of St. Bartholomew, as well as between those ports and all other foreign countries and places; but the vessels of neither party will be entitled to share in the coasting trade of the other". Mr. Clay said that the "President was anxious to secure the adoption of the general principle without qualifications". If the variations made in order to secure the adoption of this principle should be rejected, Mr. Appleton was authorized to renew the old treaty with the exception of articles third, fourth, and sixth. ${ }^{60}$

${ }^{60}$ Messages and Papers, II, 919; Senate Documents, 19 Cong., 2 sess., No. 1, p. 6; Am. State Papers, For. Rel., VI. 208.

${ }^{37}$ Abridgement of Debates, IX, 428-9.

${ }^{68}$ Am. State Papers, For. Rel., VI, 368, 719.

${ }^{60}$ Am. State Papers, For. Rel., VI, 719.

${ }^{\infty}$ Am. State Papers, For. Rel., VI, 720. 
It had been reported to Washington that a treaty had been concluded between the Governments of Sweden and Great Britain, which gave a considerable advantage to British vessels. $\mathrm{Mr}$. Appleton investigated and found that the alleged advantage consisted in certain port dues. From the report submitted it is gathered that on 100 vessels the total charges for Swedish vessels were $\$ 101.07$, for American vessels $\$ 112.34$, and for British vessels $\$ 110.57$. Those figures show that the difference in port dues between the vessels of the United States and Sweden in Swedish ports was $\$ 11.27$, and between the vessels of the United States and Great Britain was less than two dollars. ${ }^{61}$

The negotiations proceeded from April 5, when Mr. Appleton announced that he was authorized and ready to negotiate, till July 11, when he notified his Government that the new treaty had been signed. ${ }^{62}$

The new treaty placed the vessels of the United States in the ports of Sweden, Norway, and the Island of St. Bartholomew on a footing of "perfect equality with vessels of those countries", in regard to the general import and export trade. The duties and "charges of all kinds were the same for vessels of both parties". The products of the United States were admitted into Sweden, Norway, and St. Bartholomew on the same terms as similar products from any other foreign country; into Sweden and Norway on "the same terms as similar products from their West India colony, and into the colony as similar products from the mother country".

The only exception to these principles were the following:

1. In regard to vessels, the reserve was "made by each State of its own coasting trade";

2. In regard to both vessels and products a reserve was made by Sweden and Norway of their trade with Finland;

${ }^{61}$ Am. State Papers, For. Rel., VI, 721.

${ }^{62}$ Am. State Papers, For. Rel., VI, 720, 725. 
3. In regard to products alone, a reserve was made by Sweden and Norway "of particular advantage to the tallow and tallow candles from Russia". ${ }^{\text {es }}$

The treaty was submitted to the Senate for advice with regard to its ratification on December $12,1827,{ }^{64}$ and this body practically without discussion advised its ratification January 7 , 1828, and the ratifications were exchanged January 18, 1828. On the following day the President issued a proclamation declaring the treaty in force. ${ }^{65}$

This then may for all practical purposes be considered the close of the early negotiations. In 1830, the two countries had exchanged public ministers, settled the claims which grew out of an application of the continental system, established a firm relation based on treaties, and had consular representatives each in the more important ports of the other. All regular relations had therefore been established at that time and the Presidents have announced to succeeding sessions of Congress that "with the Government of..... Sweden..... the best understanding exists. Commerce..... is fostered and protected by reciprocal good will, under the sanction of liberal conventional and legal provisions'". ${ }^{68}$

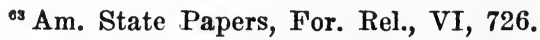

${ }^{\circ 4}$ Messages and Proclamations, II, 959; Am. State Papers, For. Rel., VI, 707.

${ }^{65}$ Malloy, Treaties and Conventions, II, 1748.

Journal of the Senate (1834-5), 6; Messages and Papers, II, 1316; Senate Documnts, 24 Congress, 1 sess., I, 5. 


\section{SELECT BIBLIOGRAPHY}

\section{A. Contemporary Material.}

Official and Semi-official Documents.

Abridgement of Debates (1789-1856), New York, 1860; 16 vols. Adlersparre, G. (ed.), Handlingar rörande Sveriges äldre, nyare och nyaste Historia, Stockholm, 1832; 7 vols.

Alin, O. (ed.), Historiska Handlingar, XVII, Stockholm, 1899.

American State Papers, Foreign Relations, Washington, 1832$1859 ; 6$ vols.

American State Papers, Commerce and Navigation, Washington, 1832-1834; 2 vols.

Annals of Congress, Washington, 1834-1856; 42 vols.

Journals of the American Congress, Washington, 1823; 4 vols.

Journals of the Continental Congress (Ford, ed.), Washington, 1904-1914; 23 vols.

Journals of House of Representatives (1789-1815), Washington, $1826 ; 9$ vols.

House Documents, 15 Congress to 24 Congress, Washington, 1817-1837.

Manuscripts in the Department of State, Index and Archives. Register of Debates in Congress, Washington, 1825-1837; 29 vols.

Richardson, J. D. (ed.), Messages and Papers of the Presidents, Washington, $1896-1899 ; 10$ vols.

Senate Documents, 15 Congress to 24 Congress, Washington, 1817-1837.

Senate Journal, 15 Congress to 24 Congress, Washington, 18171837. 
Sbornik Imperatorskago Russkago Istoritcheskago Obstchestva,

St. Petersburg, 1867-1913; 142 vols.

Sparks, J. (ed.), Diplomatic Correspondence of the American Revolution, Boston, 1829 ; 6 vols.

Silverstolpe, C. (ed.), Historiskt Bibliotek, Stockholm, 1875$1880 ; 7$ vols.

Wharton, F. (ed.), The Revolutionary Diplomatic Correspondence of the United States, Washington, $1889 ; 6$ vols.

Works of Contemporary Authors.

Adams, C. F. (ed.), The Works of John Adams, Boston, 1856; 12 vols.

Ford, N. C. (ed.), Writings of John Quincy Adams, New York, 1913-1917; 7 vols.

Ford, P. L. (ed.), Writings of Thomas Jefferson, New York, $1892 ; 10$ vols.

Hamilton, S. M. (ed.), The Writings of James Monroe, New York, $1903 ; 7$ vols.

Hunt, G. (ed.), The Writings of James Madison, New York, $1900 ; 9$ vols.

Smyth, S. M. (ed.), The Writings of Benjamin Franklin, New York, 1905; 10 vols.

\section{Diaries and Memoirs.}

Adams, C. F., Memoirs of John Quincy Adams, Philadelphia, $1874-1877 ; 12$ vols.

Albedyhll, Baron, Recueil de memoires et autres piéces authentique, relative aux affaires de l'Europe, et particuliérement celles du Nord, pendant la demiere partie du 18: me siécle, 1798.

Harris, J. H., Diaries and Correspondence of James Harris,

First Earl of Malmesbury, London, 1844; 4 vols.

Meredith, W. G., Memorials of Charles John, King of Sweden, London, 1829. 
Murry, W. V., Diary, in manuscript in the Library of Congress, Washington, D. C.

Skjoldebrand, A. F., Memoarer, Stockholm, 1903; 2 vols.

Stedingk, Count, Memoires posthumes, Paris, 1844; 3 vols.

\section{B. Non-contemporary Material.}

Adams, Henry, History of the United States, New York, 1898$1901 ; 9$ vols.

Alin, O., Carl Johan och Sveriges yttre Politik, 1810-1815, Stockholm, 1899.

Bain, R. N., Gustavus III and his Contemporaries, 1746-1792, London, 1894 ; 2 vols.

Bancroft, G., History of the United States, Boston, 1874; 10 vols. Bergbohm, C., Die Bewaffvete Neutralitet, 1780-1783, Dorpat, 1883.

Feuk, J., Sverige pâ Kongressen i Wien, 1814-1815, Lund, 1915. Generalstabens Krigshistoriska Afdelning, Sveriges Krig, 1808 och 1809, Stockholm, 1890; 2 vols.

Grade, A., Sverige och Tilsit Alliansen, 1807-1810, Lund, $191 \%$. Granberg, P. A., Last Years of Gustavus IV Adolphus, London, 1812.

Hildebrand, E. (ed.), Historisk Tidskrift, Stockholm, 1881-1917; 37 vols.

Hildebrand, E., Sveriges Historia, Stockholm, 1905-1910, vols. VIII-X.

Hjärne, H., Historiska Studier, Stockholm, 1908.

Lyman, T., The Diplomacy of the United States, Boston, 1826. McMaster, J. B. Life and Times of Stephen Girard, Philadelphia, 1918; 2 vols.

Nilsson, J. W., De Diplomatiska förbindelserna mellan Sverige och Frankrike under Gustaf IV Adolf, Upsala, 1899.

Säve, T., Sveriges Historia, Stockholm, 1881; vol. VI. 
Tengberg, R., and Boethius, S., Sveriges Historia, Stockholm, 1879 ; vol. V.

Trescot, W. H., Diplomacy of the Revolution, New York, 1852. Trescot, W. H., The Diplomatic History of the Administration of Washington and Adams, 1789-1801, Boston, 1857. 





\section{GENERAL LIBRARY \\ UNIVERSITY OF CALIFORNIA-BERKELEY \\ RETURN TO DESK FROM WHICH BORROWED \\ This book is due on the last date stamped below, or on the date to which renewed. \\ Renewed books are subject to immediate recall.}

ONE MONTH AFTER RECEITT

INTER LIBRARY SANTA BARBARA LOAN INTERLIBRARY LOAN NON-RENEWABLLF OV 174369 JUL 231964 ONE MONTH AFT RR RECUET

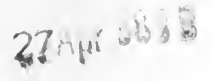
GUES WOWTH AFTER RECEPT

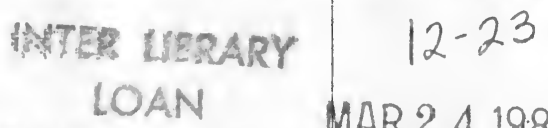
MAR 241982 RECD LD APR 13 n. JUL 231964 INTERLIBRARY LOAN 18:"Iar'63EF REC'D LD.

AUG 191964 STACK DEAD MAR 41953 LD 21-100m-1,'54(1887s16)476 
YC 06429

18

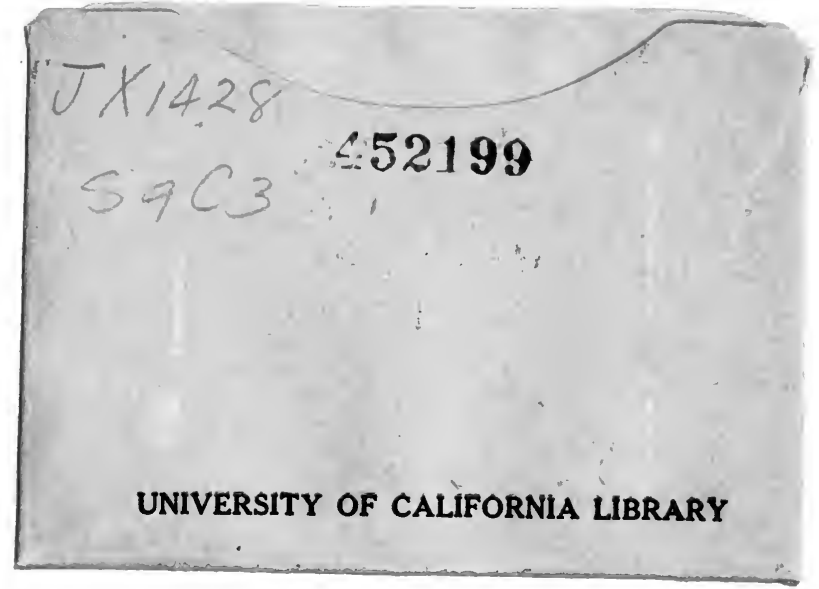


